\title{
Recycling of Marine Carbonate Induced Calcium Isotope Heterogeneity of Arc
}

\author{
Magmas in Subduction Zones \\ Xue-Gang Chen*a, Tao Wu ${ }^{\mathrm{a}}$, Qin Gao ${ }^{\mathrm{a}}$, Yu-Ming Lai ${ }^{\mathrm{b}}$ \\ ${ }^{a}$ Ocean College, Zhejiang University, Zhoushan 316021, China \\ ${ }^{\mathrm{b}}$ Department of Earth Sciences, National Taiwan Normal University, Taipei 11677, Taiwan \\ Corresponding author: Xue-Gang Chen, email: chenxg83@zju.edu.cn, Tel: +86-580-2092326, Fax: +86-580- \\ 2092891.
}

\begin{abstract}
Calcium $(\mathrm{Ca})$ is an essential element constituting sedimentary carbonate in subducting sediments. Ca isotopic characteristics of subduction-related rocks could provide insight into the behavior and budget of carbonate and carbon cycles in subduction zones, due to the distinctive $\delta^{44 / 40} \mathrm{Ca}$ ranges of sedimentary carbonate with respect to the mantle. Here, we studied the Ca isotopic compositions of arc magmas from the Northern Luzon arc (NLA), which are evolved from a depleted mantle metasomatized by slab-derived fluids and sediment melts. The $\delta^{44 / 40} \mathrm{Ca}$ values range from $0.76 \pm 0.04 \%$ to $1.01 \pm 0.03 \%$ and cover the typical ranges for bulk silica earth (BSE, $\sim 0.94 \%$ ) and fresh mid-ocean ridge basalt (MORB, $\sim 0.83 \%$ ). The Ca isotopes of NLA volcanics are not dominantly determined by the effects of mantle partial melting or fractional crystallization, nor significantly modified by secondary alteration. Instead, the $\delta^{44 / 40} \mathrm{Ca}$ values of NLA volcanics are controlled by the subduction-related metasomatism. The metasomatism by slab-derived fluids (mainly expelled from altered oceanic crust, AOC) dramatically elevated the contents of fluid-mobile elements (e.g., $\mathrm{Ba}$ and $\mathrm{Pb}$ ) with respect to fluid-immobile elements (e.g., Ce). This process, however, rarely modified the Ca isotopes, possibly ascribed to the $\delta^{44 / 40} \mathrm{Ca}$ similarity between $\mathrm{AOC}$ and the depleted mantle. The $\delta^{44 / 40} \mathrm{Ca}$ values significantly correlated with subduction indicators (e.g., $\mathrm{Sr}-\mathrm{Nd}$ isotopes, $\mathrm{Ba} / \mathrm{Nb}, \mathrm{Ce} / \mathrm{Pb}$, and $\mathrm{Nb} / \mathrm{La}$ ), demonstrating the $\mathrm{Ca}$ isotopes of NLA volcanics are mainly controlled by the metasomatism of sediment melts subducting from the South China Sea (SCS). Based on the thermal structures and chemical compositions of sediments subducting into global trenches, we propose that carbonate $\mathrm{Ca}$ isotopic signals can only be observed in the arcs with high sedimentary Ca fluxes and temperaturepressure conditions well beyond the solidus of $\mathrm{H}_{2} \mathrm{O}$-saturated sediment melting, e.g., NLA, Nicaragua, Guatemala, Colombia, Peru, South Chile, North Vanuatu, New Zealand, and Kermadec. The absence of such signals in other
\end{abstract}


arcs suggests either limited sedimentary fluxes or much of the subducting sedimentary carbonate has been survived during plate subduction to enter the deep mantle.

Keywords: Carbonate recycling; Ca isotopes; Subduction zone; Sediment melts; Arc magmas; Slab-derived fluids

\section{Introduction}

As one of the major elements forming the bulk silicate earth, Calcium $(\mathrm{Ca})$ is a fluid-mobile element linking the Earth's lithosphere, hydrosphere, biosphere, and atmosphere (Tipper et al., 2008; Fantle and Tipper, 2014). The source, sink, and evolution of Ca between Earth's layered structures are essential for understanding the formation and evolution of rocky planets, as well as the global biogeochemical $\mathrm{Ca}$ and carbon cycles (Farkaš et al., 2011; Valdes et al., 2014; Huang and Jacobsen, 2017). Specifically, Ca isotopic composition (usually denotes as $\delta^{44 / 40} \mathrm{Ca}$ with respect to SRM915a) is an important geochemical and biogeochemical indicator due to its different ranges and fractionation behaviors in high-temperature igneous processes and low-temperature near-surface environments (DePaolo, 2004; Farkaš et al., 2007; Nielsen et al., 2012; Antonelli and Simon, 2020). For instance, there is an $8 \%$ variation in the $\delta^{44 / 40} \mathrm{Ca}$ values of various Ca reservoirs on Earth while igneous rocks show $\delta^{44 / 40} \mathrm{Ca}$ ranging from -0.9 to $+0.9 \%$ with respect to bulk silicate Earth (BSE, $\delta^{44 / 40} \mathrm{Ca}=0.94 \pm 0.05 \%$ ) (Fantle and Tipper, 2014; Kang et al., 2017; Chen et al., 2019; Antonelli and Simon, 2020).

Because carbonate precipitation, either biogenic or inorganic, preferably removes lighter $\mathrm{Ca}$ isotopes from seawater (Gussone et al., 2005, 2016), sedimentary carbonate usually shows distinctive Ca isotopic compositions (mostly $0.4 \sim 0.8 \%$, global average 0.6\%o) than BSE (Farkaš et al., 2007; Fantle and Tipper, 2014 and references therein; Kang et al., 2017). As a result, the variation of $\delta^{44 / 40} \mathrm{Ca}$ in the Earth's materials could provide insights into the recycling of carbonate and carbon in subduction zones (Fantle and DePaolo, 2005; Liu et al., 2017; Plank and Manning, 2019; Lu et al., 2020). Subduction zones are regions where a hydrated oceanic plate subducted beneath another plate. With the increasing subduction depth, the fluid expelled from the downgoing plate progressively evolves from highly aqueous beneath the forearc to less aqueous sediment melts (Stern, 2002; Ribeiro et al., 2013). Fluid mobile elements (e.g., $\mathrm{Cs}, \mathrm{Rb}, \mathrm{Ba}, \mathrm{Sr}$, and $\mathrm{K}$ ) are released along with slab-derived fluids into the mantle wedge. Beneath the island arc, the magmas are produced by the partial melting of a depleted mantle (DMM) metasomatized by slab-derived fluids and/or sediment melt (Stern, 2002; Kawamoto et al., 2012). As a result, arc magmas could record the signals of subducting sediment and slab-derived fluids (Plank and Langmuir, 1993; Ribeiro et al., 2013). Besides recycling back to the arc, the subducting marine carbonate could further enter the 
deep mantle (Plank and Langmuir, 1993; Stern, 2002). Mantle metasomatism by the recycled carbonate has been proposed to affect the $\delta^{44 / 40} \mathrm{Ca}$ values of corresponding igneous rocks (e.g., Hawaiian tholeiites, Huang et al., 2011; mantle xenoliths, Kang et al., 2016, 2019; Chen et al., 2018; carbonatites, Amsellem et al., 2020; and meta-basaltic rocks from the Dabie-Sulu Orogen, Lu et al., 2020).

However, it is argued that Ca isotopes cannot distinguish "carbonatite" and "silicate" types of mantle metasomatism (Ionov et al., 2019). In addition, the $\delta^{44 / 40} \mathrm{Ca}$ values of back-arc basin basalts (BABBs) from southwestern Pacific are essentially comparable to that of fresh mid-Ocean Ridge Basalts (MORBs), possibly attributed to the low carbonate abundance in the subducting Pacific sediment (Zhu et al., 2020a). Currently reported arc magmas, which are affected by slab-derived fluids and/or subducting sediments, also exhibit MORB-like $\delta^{44 / 40} \mathrm{Ca}$ values and show insignificant correlations with subduction indicators (e.g., Ba/La and Th/Nb) (Wang et al., 2021; Kang et al., 2021). These results could be ascribed to the limited Ca budget in the slab-derived fluids, buffering effect of the mantle wedge, carbonate hosting by altered oceanic crust (AOC), and/or survival of carbonate during plate subduction (Wang et al., 2021; Kang et al., 2021). Therefore, despite 20\% of the element budget in subducting sediment is recycled back to the arc (Plank and Langmuir, 1993), we still lack direct evidence showing $\mathrm{Ca}$ isotopic variations of arc volcanic rocks induced by subducting materials. The recycling of carbonate and associated carbon cycle in subduction zones require to be better constrained by studies on the Ca isotopic characteristics of representative arc magmas.

Here, we present a systematic $\mathrm{Ca}$ isotope study on the arc magmas with diverse rock types and chemical compositions from the Lutao island, Northern Luzon arc (NLA). The NLA is one of the major intra-oceanic arcs in the Western Pacific. It is triggered by the eastward subduction of the South China Sea (SCS) Plate beneath the Philippine Sea Plate (Bowin et al., 1978). Petrological and geochemical investigations indicate the NLA volcanics are typical arc magmatic products with significantly enrichment of large ion lithophile elements (LILEs) with respect to high field strength elements (HFSEs) (Yang, 1992; McDermott et al., 1993). In addition, the NLA volcanics may have been evolved from a depleted mantle (DMM) metasomatized by both slab-derived fluids and sediment melts (McDermott et al., 1993; Marini et al., 2005), and probably experienced additional contamination by continental crust materials (Yang, 1992; Lai et al., 2018). Therefore, this set of rock samples offer us an opportunity to evaluate the effects of slab-derived fluids, sediment melt, and crustal contamination on the Ca isotopic characteristics of arc magmas; and this research will help better understanding the flux and budget of carbonate and carbon recycling in subduction zones. 


\section{Geological setting}

Volcanism in the Luzon arc commenced during the late Eocene and lasted until the middle Miocene, due to the subduction of the Indian Ocean plate underneath the Philippine Sea Plate (Mukasa et al., 1987; Knittel et al., 1988). Volcanism in the NLA initiated at 35 - 17 Ma because of the subduction of the SCS Plate beneath the Philippine Sea Plate (Taylor and Hayes, 1983). Subsequently, NLA collided with the Eurasian Plate and was accreted onto the continental margin (Biq, 1971; Suppe, 1981, 1984).

Lutao is one of the volcanic islands situates at the NLA. According to the K-Ar dating results of the xenolith from this island, volcanism in Lutao can be traced to older than 4 Ma (Juang and Chen, 1990), however, the major volcanism started at $\sim 2.0 \mathrm{Ma}$ and ceased at $\sim 0.54 \mathrm{Ma}\left(\mathrm{K}-\mathrm{Ar}\right.$, Richard et al., 1986; ${ }^{40} \mathrm{Ar}-{ }^{39} \mathrm{Ar}$, Lo et al., 1994 ; zircon fission-track, Yang et al., 1995; Rb-Sr mineral isochron ages, Lan et al., 1986; and zircon U-Pb, Shao et al., 2014). It develops four volcanic sequences: the Ameishan volcanic breccia, the Niutzushan andesite, the Kungkuan andesite, and the Huoshaoshan andesite (Yang, 1992; Chen et al., 1994). The Lutao volcanic rocks belong to calcalkaline medium-K and range from basalt to dacite but are dominated by andesite (Chen and Lin, 1980; Chen, 1986; Yang, 1992). Phenocrysts in the Lutao rocks are dominated by plagioclase (Pl) and hornblende (Hbl), while olivine (Ol) and clinopyroxene (Cpx) are also observed in some cases (Chen and Lin, 1980; Wang and Chung, 1991). Some samples in Kungkuan andesites show significant enrichment in light rare earth element (LREE) might be related to the lower crust contamination (Chen et al., 1990; Yang, 1992). Moreover, whole rock Nd and Hf isotopic ratios and zircon Hf isotope results show a binary mixing of magmas between DMM and continental crust materials in NLA, and especially significant in Lutao area (Yang, 1992; Lai et al., 2018).

\section{Analytical Methods}

Fresh volcanic rocks were collected across the Lutao island, NLA (Fig. 1), as described in Yang (1992). Only the breccia-free volcanics are chosen for subsequent analyses and discussions.

\subsection{Minerals}

Thin sections of the arc volcanic samples were observed by a Leica optical microscopy. The mineral phases were performed for major elements on a four-spectrometer Jeol JXA 8100 electron probe microanalyzer in the Key Laboratory of Submarine Geoscience, Second Institute of Oceanography, Ministry of Natural Administration 
of China. The operation conditions were: accelerating potential of $15 \mathrm{kV}$, beam current of $20 \mathrm{nA}$, counting time of $20 \mathrm{~s}$, and spot size of $10 \mu \mathrm{m}$. Natural mineral standards and ZAF correction scheme were used for calibration.

\subsection{Major and trace elements}

All the geochemical analyses including analyses on major and trace elements, Sr-Nd isotopic compositions, and $\mathrm{Ca}$ isotopes are conducted at the Wuhan Sample solution Analytical Technology Co., Ltd., Wuhan, China.

The rock samples were grounded into 200 mesh and dried for $12 \mathrm{~h}$ in a temperature-controlled oven at 105 ${ }^{\circ} \mathrm{C}$. Then $1.0 \mathrm{~g}$ dried sample was accurately weighted and heated in a muffle furnace at $1000{ }^{\circ} \mathrm{C}$ for $2 \mathrm{~h}$. The weight difference after heating is used to calculate the loss on ignition (LOI). About $0.6 \mathrm{~g}$ sample powder was mixed with $6.0 \mathrm{~g}$ cosolvent $\left(\mathrm{Li}_{2} \mathrm{~B}_{4} \mathrm{O}_{7}: \mathrm{LiBO}_{2}: \mathrm{LiF}=9: 2: 1\right)$ and $0.3 \mathrm{~g}$ oxidant $\left(\mathrm{NH}_{4} \mathrm{NO}_{3}\right)$ in a Pt crucible. The mixture was heated at $1150{ }^{\circ} \mathrm{C}$ for $14 \mathrm{~min}$. The obtained melt was quenched with air for $1 \mathrm{~min}$ to produce flat discs on the fire brick and was subsequently determined for major elemental contents using an X-ray fluorescence (Primus II, Rigaku, Japan). Measurements on duplicate samples and standard samples (GBW07104, GBW07105, and GBW07111) demonstrate measurement uncertainties of $<5 \%$.

Trace elemental analysis of the rock samples were conducted on Agilent 7700e ICP-MS after the sample powder was fully digested by $\mathrm{HNO}_{3}$ and $\mathrm{HF}$ solutions. The measurement quality was controlled by duplicate analyses, blank samples, and analyses on standard samples (AGV-2, BHVO-2, BCR-2, and RGM-2). The overall measurement uncertainties are less than $5 \%$.

\subsection{Ca isotopes}

Ca isotopic analyses of Lutao volcanics were performed on a Neptune Plus MC-ICP-MS (Thermo Fisher Scientific, Dreieich, Germany) equipped with a quartz dual cyclonic-spray chamber (Elemental Scientific Inc.,

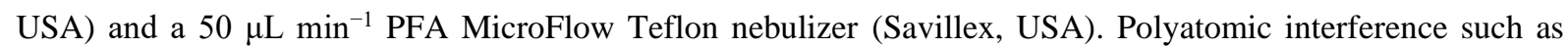
${ }^{40} \mathrm{Ar}^{1} \mathrm{H}^{2+}$ and ${ }^{14} \mathrm{~N}^{3+}$ was resolved by medium resolution mode. An in-house Alfa Ca standard solution (Lot: 9192737) was used as a bracketing reference standard. All Ca isotope results were reported relative to NIST SRM915a by adding a conversion factor of 0.58 (the $\delta^{44 / 42}$ Casrm915a value of Alfa Ca) (Eq. 1). The instrumental precision and accuracy during routine $\mathrm{Ca}$ isotope measurements were monitored by intermediate measurements of NIST SRM915a. The accuracy and reproducibility were controlled by analyses of a calcium carbonate standard NIST SRM915b, a basalt standard BHVO-2, and standard seawater samples.

$$
\delta^{44 / 42} \mathrm{Ca}=\left(\frac{\left({ }^{44} \mathrm{Ca} /{ }^{42} \mathrm{Ca}\right)_{\text {sample }}}{\left({ }^{44} \mathrm{Ca} /{ }^{42} \mathrm{Ca}\right)_{\text {SRM915a }}}-1\right) \times 1000 \% 0
$$


In order to compare our results with previous studies, the $\delta^{44 / 42} \mathrm{Ca}$ values in this study are converted to $\delta^{44 / 40} \mathrm{Ca}$ using the following equation (Gussone et al., 2016):

$$
\delta^{44 / 40} \mathrm{Ca} \approx \delta^{44 / 42} \mathrm{Ca} \times 2.048
$$

The long-term ( $>3$ months) average $\delta^{44 / 42} \mathrm{Ca}$ of NIST 915a is $0.001 \pm 0.058 \%$ ( $\left.2 \mathrm{SD}, \mathrm{n}=155\right)$, indicating the reproducibility of the instrument is better than $0.06 \%$ ( 2 SD). The repeatedly analyzed NIST SRM $915 \mathrm{~b}$, BHVO2, and seawater are $0.40 \pm 0.04 \%$ ( $2 \mathrm{SD}, \mathrm{n}=3), 0.37 \pm 0.00 \%$ ( $2 \mathrm{SD}, \mathrm{n}=3)$ and $0.94 \pm 0.04 \%$ o $(2 \mathrm{SD}, \mathrm{n}=3)$, respectively. These results are consistent with previous studies within analytical uncertainty, confirming the accuracy of our analytical method for $\mathrm{Ca}$ isotopes in geological samples (Amini et al., 2008; Heuser and Eisenhauer, 2008; Kang et al., 2017; Feng et al., 2018). In addition, all the measured Ca isotopic compositions follow the theoretical mass-dependent fractionation line between $\delta^{43 / 42} \mathrm{Ca}$ and $\delta^{44 / 42} \mathrm{Ca}$ with a slope of 0.506 (Fig. S1) (Heuser, 2016), further demonstrating the reliability of our Ca isotopic analyses.

\subsection{Sr-Nd isotopic compositions}

$\mathrm{Sr}$ and Nd isotope analyses were performed on a Neptune Plus MC-ICP-MS (Thermo Fisher Scientific, Dreieich, Germany). Sr and Nd single element solution from Alfa (Alfa Aesar, Karlsruhe, Germany) was used to optimize instrument operating parameters. Aliquots of the international standard solution of $200 \mu \mathrm{g} \mathrm{L}{ }^{-1}$ NIST SRM 987 and JNdi-1 were used regularly for evaluating the reproducibility and accuracy of the instrument. The interference element $\mathrm{Sm}$ has been completely separated by the exchange resin process. The remaining interference of ${ }^{144} \mathrm{Sm}^{+}$was corrected using the method described by (Lin et al., 2016). Analyses of the NIST SRM 987 standard solution yielded ${ }^{87} \mathrm{Sr} /{ }^{86} \mathrm{Sr}$ ratio of $0.710244 \pm 22(2 \mathrm{SD}, \mathrm{n}=32)$, which is identical within error to the published values (0.710241 \pm 12 , Thirlwall, 1991). The analyzed ${ }^{143} \mathrm{Nd} /{ }^{144} \mathrm{Nd}$ ratio of JNdi-1 standard is $0.512118 \pm 15(2 \mathrm{SD}, \mathrm{n}=31)$, consistent with previous reported values $(0.512115 \pm 07$, Tanaka et al., 2000). The USGS reference materials BCR2 (basalt) and AGV-2 (andesite) yielded results of $0.705009 \pm 8(2 \mathrm{SD}, \mathrm{n}=4)$ and $0.703984 \pm 10(2 \mathrm{SD}, \mathrm{n}=4)$ for ${ }^{87} \mathrm{Sr} /{ }^{86} \mathrm{Sr}$, respectively, and $0.512641 \pm 8(2 \mathrm{SD}, \mathrm{n}=6)$ and $0.512787 \pm 8(2 \mathrm{SD}, \mathrm{n}=4)$ for ${ }^{143} \mathrm{Nd} /{ }^{144} \mathrm{Nd}$, respectively, which are also in conformity with published values (Zhang and $\mathrm{Hu}, 2020$ ).

\section{Results}

\subsection{Chemical compositions}

The arc magmas from Lutao island, NLA range from basalt to andesite but are dominated by calc-alkaline andesite (Fig. S2) (Chen and Lin, 1980; Yang, 1992; McDermott et al., 1993). These volcanic rocks show large 
variations of major elements (Table S1). Both the $\mathrm{Na}_{2} \mathrm{O}+\mathrm{K}_{2} \mathrm{O}$ and $\mathrm{K}_{2} \mathrm{O}$ contents generally increase with $\mathrm{SiO}_{2}$ concentrations. The $\mathrm{SiO}_{2}$ contents vary from 51.16 wt. $\%$ to 62.17 wt. $\%$ and the $\mathrm{MgO}$ concentrations fall in a range of between 1.87 wt. $\%$ and 6.53 wt. $\%$. CaO contents range from 4.91 wt. $\%$ to 10.64 wt. $\%$ with an average value of 7.96 wt.\%. The Lutao volcanics demonstrate relatively constant $\mathrm{Al}_{2} \mathrm{O}_{3}$ and $\mathrm{Na}_{2} \mathrm{O}$ contents, with average values of 18.03 wt. $\%$ and $3.20 \mathrm{wt} \%$, respectively.

All the volcanic rocks present large ranges for trace elements and REEs (Table S1). Both the trace element and REE distribution patterns are comparable with previously published data on NLA volcanics (Fig. S3) (Yang, 1992; Marini et al., 2005; Lai et al., 2017). These samples show significant enrichment of LILEs (e.g., Cs, Rb, Ba, $\mathrm{Pb}$ ) and some HFS elements (Th and $\mathrm{U}$ ) with respect to primitive mantle, while most HFS elements (e.g., Zr, Hf, $\mathrm{Nb}, \mathrm{Ti}$, and REEs) are slightly enriched. All the Lutao volcanics show significant LREE enrichment with respect to heavy rare earth elements (HREEs). No significant Eu and Ce anomalies are observed.

The minerology of the arc magmas is dominated by $\mathrm{Pl}, \mathrm{Hbl}, \mathrm{Cpx}$, and orthopyroxene (Opx). Ol was only observed in the samples with relatively lower $\mathrm{SiO}_{2}$ contents (e.g., LT2-FT1A and LT2-10A) (Table S3). The major elements for mineral phases demonstrate similar compositions of Cpx, Hbl, and Opx between samples (Table S2). For instance, all the analyzed $\mathrm{Cpx}$ crystals exhibit constant $\mathrm{SiO}_{2}, \mathrm{MgO}$, and $\mathrm{CaO}$ contents of $51.8 \pm 1.3$ wt.\%, 15.9 \pm 1.3 wt.\%, and $21.3 \pm 2.1$ wt.\%, respectively. The $\mathrm{SiO}_{2}$ and $\mathrm{CaO}$ contents of $\mathrm{Hbl}$ crystals show narrow ranges of $44.6 \pm 1.7$ wt. $\%$ and $11.0 \pm 0.8$ wt. $\%$, respectively. By contrast, the Lutao rock samples show great variations for $\mathrm{Pl}$ compositions. According to the $\mathrm{CaO}$ contents of minerals and mineral modes, $\mathrm{Ca}$ in the Lutao arc magmas is mainly hosted by Cpx, Hbl, and Pl (Table S3).

\subsection{Isotopic compositions}

The Lutao arc magmas show large variations of ${ }^{87} \mathrm{Sr} /{ }^{86} \mathrm{Sr}$ ratios ranging from 0.704167 to 0.705290 . Correspondingly, the $\mathrm{Nd}$ isotopic compositions $\left({ }^{143} \mathrm{Nd} /{ }^{144} \mathrm{Nd}\right)$ fall in a range of between 0.512528 and 0.512737 (Table 1, Fig. S5). These values are similar to previous published results on NLA volcanics and close to the typical Sr-Nd isotopic range of BSE (Chen et al., 1990; McDermott et al., 1993).

The arc magmas show $\delta^{44 / 40} \mathrm{Ca}$ values between $0.76 \pm 0.04 \%$ and $1.01 \pm 0.03 \%$ with an average of $0.90 \pm$ $0.16 \%$ (2SD, $\mathrm{n}=10)$ (Table 1$)$. These values are significantly different than the global marine carbonate and carbonate-rich sediments (Fantle and Tipper, 2014; Zhu et al., 2020c; Amsellem et al., 2020). All the samples could be classified as one group with $\delta^{44 / 40} \mathrm{Ca}$ values of $0.97 \pm 0.05 \%$ o $(2 \mathrm{SD}, \mathrm{n}=5)$ and one group with $\delta^{44 / 40} \mathrm{Ca}$ of $0.82 \pm 0.08 \%$ ( $2 \mathrm{SD}, \mathrm{n}=5)$. The first group is close to the accepted $\delta^{44 / 40} \mathrm{Ca}$ range of BSE $(0.94 \pm 0.05 \%$ ) (Kang et 
al., 2017), while the second group is similar to the $\delta^{44 / 40} \mathrm{Ca}$ values of average BABBs $(0.80 \pm 0.08 \%$ ) and average MORBs (0.83 \pm 0.11\%o) (Chen et al., 2019; Zhu et al., 2020a, b; Antonelli and Simon, 2020) (Fig. 2). Furthermore, the Lutao arc magmas show similar ranges with that previously reported arc magmas from Tonga, Mariana, Central America, Southern Lesser Antilles, and Central-eastern Aleutian arcs (Wang et al., 2021; Kang et al., 2021).

\section{Discussion}

The Quaternary Lutao volcanism occurred within a short period of time, which developed the Ameishan volcanic breccia $(1.44 \sim 1.54 \mathrm{Ma})$, the Niutzushan andesite $(1.28 \mathrm{Ma})$, the Kungkuan andesite $(1.24 \sim 1.36 \mathrm{Ma})$, and the Huoshaoshan andesite (1.24 Ma) in sequence (Yang, 1992; Chen et al., 1994; Shao et al., 2014). The Lutao volcanic rocks are far more evolved than a direct melt of the mantle wedge beneath the island arc on accounts of the significantly lower $\mathrm{MgO}$ contents than the primary magmas and lower $\mathrm{Ni}$ and $\mathrm{Cr}$ contents than the least-evolved island arc basalts (Perfit et al., 1980). Both the significantly enrichments of LILEs (e.g., Cs, Rb, Ba, and Pb) with respect to HFSEs and the LREEs enrichment over HREEs (Fig. S3) suggest the Lutao volcanics are typical arc magmatic products (Yang, 1992; McDermott et al., 1993; Lai et al., 2017). Considering the geological setting of NLA (Fig. 1), the enrichment of LREEs and LILEs could be attributed to the subduction-related metasomatism by sediment melts and/or slab-derived fluids (McDermott et al., 1993; Fourcade et al., 1994).

Therefore, the $\sim 0.25 \%$ variation of Ca isotopic compositions in the Lutao arc magmas could be ascribed to either source effects and/or the evolution of the arc magma during magmatic/post-magmatic processes (e.g., partial melting, fractional crystallization, or seawater alteration) (Huang et al., 2011; John et al., 2012; Kang et al., 2017; Antonelli and Simon, 2020; Chen et al., 2020b). In addition to these mass-dependent fractionation processes, the Ca isotopic characteristics could be potentially affected by the radiogenic decay of ${ }^{40} \mathrm{~K}\left(\tau_{1 / 2}=1.277 \times 10^{9}\right.$ a) $($ Fantle and Tipper, 2014). However, this process should have provided negligible contribution for the ${ }^{40} \mathrm{Ca}$ of the Lutao arc magmas because our $\mathrm{Ca}$ isotope results were calculated from measured ${ }^{44} \mathrm{Ca} /{ }^{42} \mathrm{Ca}$ ratios (Eq. 1). This statement is further supported by the low K/Ca ratios (mean 0.14) and young ages (<3 Ma) of the studied arc magmas (Yang, 1992).

\subsection{Negligible influence of secondary alteration}

The arc magmas may have been secondary altered by seawater or hydrothermal fluids. Because chemical weathering and/or fluid alteration on the igneous rocks would result in the hydration of glasses and formation of hydrous minerals, LOI is an essential indicator of the alteration degree (Banerjee and Chakrabarti, 2018). Previous 
works indicate seawater/hydrothermal alteration would significantly influence the $\delta^{44 / 40} \mathrm{Ca}$ of igneous rocks at high LOI values (e.g., > 4 wt.\%) (John et al., 2012; Blättler and Higgins, 2017; Valdes et al., 2019; Chen et al., 2020a). For instance, severe hydrothermal alteration (LOI of $4.5 \mathrm{wt.} \%)$ has induced a higher $\delta^{44 / 40} \mathrm{Ca}$ value $(1.08 \pm 0.17 \%$ ) on gabbroic rocks when compared with fresh rocks $\left(\delta^{44 / 40} \mathrm{Ca}\right.$ of $\left.0.78-0.95 \%\right)$ (Chen et al., 2020a).

The whole rock samples of the Lutao arc volcanics present LOI values of $<2 \mathrm{wt} . \%$, suggesting the secondary alteration is quite limited. Limited secondary alteration is also testified by lacking Ce anomalies $(\mathrm{Ce} / \mathrm{Ce} *$ in the Lutao volcanics, 0.96 - 1.02) and significant correlations between Sm, Sr, and Nd (Polat and Hofmann, 2003; Valdes et al., 2019). The correlation between LOI and $\delta^{44 / 40} \mathrm{Ca}$ values is not significant, indicating secondary alteration has placed negligible influence on the Ca isotopic characteristics of Lutao arc magmas (Fig. 3). This statement is further supported by the ratios between alteration sensitive elements (e.g., $\mathrm{Rb}, \mathrm{Pb}, \mathrm{U}$, and $\mathrm{Sb}$ ) and insensitive elements (e.g., heavy REE, Y, and $\mathrm{TiO}_{2}$ ) (Jochum and Verma, 1996). The correlations between $\delta^{44 / 40} \mathrm{Ca}$ and $\mathrm{Rb} / \mathrm{TiO}_{2}$ and $\mathrm{U} / \mathrm{Th}$ ratios show vague decreasing trends (i.e., increasing degree of alteration) (Fig. 3). The correlation coefficients, however, are not significant. Furthermore, the Lutao volcanics display chemical index of alteration (CIA) values within a narrow range and demonstrate in-significant correlation with the corresponding $\delta^{44 / 40} \mathrm{Ca}$ values. Therefore, secondary alteration is not responsible for the $\mathrm{Ca}$ isotopic variation of Lutao arc magmas.

\subsection{Fractional crystallization}

The Lutao volcanics show $\mathrm{SiO}_{2}, \mathrm{MgO}$, and $\mathrm{CaO}$ contents covering wide ranges (Table $\mathrm{S} 1$ ), possibly ascribed to fractional crystallization during the cooling of the primary basaltic magma. According to the typical phenocrysts and their chemical compositions in the volcanic rocks (Table $\mathrm{S} 2$ and S3), the decreasing $\mathrm{CaO}$ and $\mathrm{CaO} / \mathrm{Al}_{2} \mathrm{O}_{3}$ ratios with decreasing $\mathrm{MgO}$ contents suggest the accumulation of $\mathrm{Hbl}$ and/or $\mathrm{Cpx}$, or a combination of both. The crystallization of $\mathrm{Opx}$ and $\mathrm{Ol}$ should have played a minor role in controlling the variation of $\mathrm{CaO}$ with $\mathrm{MgO}$ contents (Fig. S4). Plg is unlikely to be a major accumulating phase because significant Eu anomalies $\left(\mathrm{Eu} / \mathrm{Eu}^{*}\right)$ are absent in all Lutao volcanics, since Eu is strongly partitioned into Pl with respect to other REEs (Vukadinovic, 1993). The $\mathrm{TFe}_{2} \mathrm{O}_{3}$ and $\mathrm{TiO}_{2}$ contents with decreasing $\mathrm{MgO}$ could be satisfied by the fractional accumulation of Fe-Ti bearing minerals (e.g., Hbl and Fe-Ti oxides). In summary, the fractional crystallization of the Lutao arc magma is dominated by the accumulation of $\mathrm{Cpx}$ and Hbl. The crystallization of $\mathrm{Opx}, \mathrm{Ol}$, and $\mathrm{Pl}$ is insignificant in controlling the major elemental contents of the Lutao arc magmas. 
Heavier $\mathrm{Ca}$ isotopes are enriched in phases with shorter bonds and smaller coordination numbers (Chacko et al., 2001; Huang et al., 2010, 2019; Feng et al., 2014). As a result, Opx and Ol, which possess shorter Ca-O bonds, are isotopically heavier in Ca than co-existing Cpx (Huang et al., 2010; Kang et al., 2016, 2017; Chen et al., 2019; Valdes et al., 2019), while $\mathrm{Hbl}$ and $\mathrm{Pl}$ are enriched in lighter Ca isotopes with respect to $\mathrm{Ol}$ and pyroxenes (Wang et al., 2019; Valdes et al., 2019). However, the fractional crystallization of Ol and Opx could not significantly change the $\delta^{44 / 40} \mathrm{Ca}$ values of the residual magma, due to their extremely low $\mathrm{CaO}$ contents with respect to $\mathrm{Cpx}$, Hbl, and Pl (Zhang et al., 2018; Chen et al., 2019). Zhu et al. (2018) suggested the $\delta^{44 / 40} \mathrm{Ca}$ of the residual melt would be only decreased by $<0.03 \%$ even when the magma has experienced $50 \%$ fractionation of $\mathrm{Ol}$ and $\mathrm{Opx}$. Furthermore, the accumulation of $\mathrm{Ol}$ and $\mathrm{Opx}$ was not significant during the magma cooling. $\mathrm{Cpx}, \mathrm{Hbl}$, and $\mathrm{Pl}$ are the major hosts for Ca in the arc magmas from Lutao, Northern Luzon arc (Table S3). The fractional crystallization of these Ca-rich minerals could have potentially affected the $\mathrm{Ca}$ isotopic characteristics of the residual melt. However, $\mathrm{Pl}$ is not a major accumulation phase and the $\delta^{44 / 40} \mathrm{Ca}$ values does not change significantly with Eu/Eu* ratios, indicating fractional crystallization of $\mathrm{Pl}$ does not produce measurable $\mathrm{Ca}$ isotope variations. Likewise, as indicated by the poor correlations between $\delta^{44 / 40} \mathrm{Ca}$ and $\mathrm{MgO}, \mathrm{CaO} / \mathrm{Al}_{2} \mathrm{O}_{3}$, and $\mathrm{CaO}$, the accumulation of $\mathrm{Hbl}$ and Cpx has produced limited influence on the $\mathrm{Ca}$ isotopic compositions of the Lutao arc magmas, despite both minerals are major accumulation phases (Fig. 4).

These results are consistent with previous works, demonstrating magma differentiation would produce negligible influence on the Ca isotopes of igneous rocks (Zhang et al., 2018; Chen et al., 2019; Zhu et al., 2020a; Wang et al., 2021). The Ca isotopic fractionation factor between $\mathrm{Cpx}$ and basaltic melt ( $\left.\alpha_{\mathrm{Cpx} \text {-melt }}\right)$ at magmatic temperatures is close to 1 (Chen et al., 2019, 2020a), and the residual melt would be only slightly affected by the accumulation of Cpx. This process is especially important when Cpx dominates the Ca contents. Specifically, Zhang et al. (2018) proposed the fractionation factor between Cpx and melt $\left(\Delta^{44 / 40} \mathrm{Ca}\right.$ Cpx-melt $)$ to be $(+0.09 \pm 0.07)$ $\times 10^{6} / \mathrm{T}^{2}$ and $\Delta^{44 / 40} \mathrm{Ca}_{\text {Plg-melt }}$ equals $(-0.15 \pm 0.08) \times 10^{6} / \mathrm{T}^{2}$ using first-principles calculations and ionic models. Combined with the calculated $\mathrm{Ca}$ isotope fractionation between $\mathrm{Hbl}$ and $\mathrm{Pl}$, the estimated $\mathrm{Hbl}$-melt fractionation is proposed as $\Delta^{44 / 40} \mathrm{Ca}$ hbl-melt $=(+0.06 \pm 0.10) \times 10^{6} / \mathrm{T}^{2}$ (Wang et al., 2019). Therefore, the accumulation of Hbl should have produced non-measurable impact on the $\delta^{44 / 40} \mathrm{Ca}$ of the melt during magma cooling. Combined with the measured $\mathrm{CaO}$ contents of $\mathrm{Cpx}$, the influence of $\mathrm{Cpx}$ accumulation on the $\delta^{44 / 40} \mathrm{Ca}$ of the residual melt could be expressed as:

$$
\delta^{44 / 40} \mathrm{Ca}_{\text {melt }, \mathrm{i}}=\frac{\delta^{44 / 40} \mathrm{Ca}_{\text {melt }, \mathrm{a}} \times \mathrm{CaO}_{\text {melt }, \mathrm{a}} \times(1-\mathrm{f})+\left(\delta^{44 / 40} \mathrm{Ca}_{\mathrm{cpx}} \times \mathrm{Ca}_{\mathrm{cpx}} \times \mathrm{f}\right)}{\mathrm{CaO}_{\text {melt }, \mathrm{i}}}
$$




$$
\delta^{44 / 40} \mathrm{Ca}_{\mathrm{cpx}}=\Delta^{44 / 40} \mathrm{Ca}_{\mathrm{cpx}-\mathrm{melt}}+\delta^{44 / 40} \mathrm{Ca}_{\text {melt }, \mathrm{a}}
$$

Where $f$ is the fraction of accumulated $\mathrm{Cpx} . \delta^{44 / 40} \mathrm{Ca}_{\text {melt,i }}$ and $\delta^{44 / 40} \mathrm{Ca}_{\text {melt,a }}$ are the $\mathrm{Ca}$ isotopic compositions of the melts before and after magma differentiation, respectively. The magma temperature is set at $1000 \mathrm{~K}$ (Chen, 1986). The modeling results suggest $\mathrm{Cpx}$ accumulation could not significant decrease the $\delta^{44 / 40} \mathrm{Ca}$ of the residual melt at $\Delta^{44} \mathrm{Ca}_{\mathrm{Cpx} \text {-melt }}$ of $0.09 \times 10^{6} / \mathrm{T}^{2}$, even if the $\mathrm{CaO}$ removal was solely ascribed to the crystallization of $\mathrm{Cpx}$ (Fig. 5). By contrast, if the $\Delta^{44} \mathrm{Ca}_{\mathrm{Cpx}-\mathrm{melt}}$ were set at $0.16 \times 10^{6} / \mathrm{T}^{2}$, the $\delta^{44 / 40} \mathrm{Ca}$ of the residual melt would be decreased from $0.94 \%$ at $\mathrm{CaO}$ of 11 wt.\% to $0.82 \%$ at $\mathrm{CaO}$ of $4 \mathrm{wt} . \%$. Nevertheless, this model cannot explain the large variation of $\delta^{44 / 40} \mathrm{Ca}$ and the poor relationship between $\delta^{44 / 40} \mathrm{Ca}$ and $\mathrm{CaO}$ contents of the Lutao arc magmas. In addition, the influence of $\mathrm{Cpx}$ accumulation has been largely exaggerated by assuming all the $\mathrm{CaO}$ removal was attributed to the fractional crystallization of Cpx. In conclusion, although the fractional crystallization of Ca-rich phases (e.g., $\mathrm{Pl}$ and Cpx) could generate measurable $\delta^{44 / 40} \mathrm{Ca}$ variations in some cases (Valdes et al., 2019; Zhu et al., 2021), the $\mathrm{Ca}$ isotopic variations in this study are less influenced by the accumulation of $\mathrm{Pl}, \mathrm{Hbl}$, and $\mathrm{Cpx}$.

Furthermore, we preliminarily estimated the $\delta^{44 / 40} \mathrm{Ca}$ values of the dominant Ca-bearing minerals in the Lutao arc magmas using the mineral mode (Table S4) and Ca isotopic fractionation between minerals. The Ca isotopic fractionation between $\mathrm{Hbl}$ and $\mathrm{Plg}\left(\Delta^{44 / 40} \mathrm{Ca}\right.$ Hbl-Plg $)$ is proposed as $0.205 \pm 0.04 \times 10^{6} / \mathrm{T}^{2}$ according to the analyses on coexisting $\mathrm{Hbl}$ and Plg of Dabie granitoids (Wang et al., 2019). The equilibrium Ca isotope fractionation in Cpx, Opx, and Plg (anorthite) have been calculated by first-principles (Wang et al., 2017; Huang et al., 2019) using the Ca contents in measured Cpx (about 7/16) and Opx (about 1/48) crystals. Except for LT2-FT2, all the other samples demonstrate almost identical Ca isotopes for $\mathrm{Cpx}$, Opx, $\mathrm{Hbl}$, and $\mathrm{Plg}$, with average $\delta^{44 / 40} \mathrm{Ca}$ values of 1.00 $\pm 0.06 \%$ o $1.60 \pm 0.06 \%$, $1.02 \pm 0.06 \%$, and $0.82 \pm 0.06 \%$, respectively.

\subsection{Partial melting}

The mantle partial melting could significantly fractionate $\mathrm{Ca}$ isotopes, ascribed to the isotopic fractionation between Ca-bearing minerals and melting priority of these minerals (Kang et al., 2016; Chen et al., 2019, 2020b; Ionov et al., 2019). Cpx, Opx, and $\mathrm{Ol}$ are the dominant Ca-bearing minerals in mantle peridotites, where Cpx is enriched in lighter Ca isotopes than co-existing Opx and Ol (Huang et al., 2010; Kang et al., 2016; Chen et al., 2019). During mantle melting, Cpx is preferential breakdown than Opx in the residue (Green, 1973; Jaques and Green, 1980). As a result, lighter Ca isotopes are preferentially transferred to the melt, while the melt-depleted peridotites and/or lherzolites are increasingly enriched in heavier Ca isotopes with increasing degree of melt- 
extraction (Kang et al., 2016, 2017; Amsellem et al., 2017; Ionov et al., 2019). Mantle melting is supposed to explain the up to $0.14 \%{ }^{44 / 40} \mathrm{Ca}$ offset of MORBs and BABBs with respect to BSE (Zhu et al., 2018, 2020a, b) and the elevated $\delta^{44 / 40} \mathrm{Ca}$ values of melting residues (Zhao et al., 2017; Kang et al., 2017; Chen et al., 2019).

However, partial melting could have produced negligible influence on the Ca isotopic characteristics of Lutao arc magmas. (1) the $\delta^{44 / 40} \mathrm{Ca}$ of the melt would be only slightly lower than the starting material using $\alpha_{\mathrm{Opx}-\mathrm{Cpx}}$ ranging from 1.00026 to 1.00050 . At $\alpha_{\mathrm{Opx}-\mathrm{Cpx}}$ of 1.00050 , partial melting would produce a melt with $\delta^{44 / 40} \mathrm{Ca}$ of 0.08\% lower than the starting peridotite (Wang et al., 2017; Zhang et al., 2018; Chen et al., 2019). (2) Partial melts from eclogites could be significantly lower $(\sim 0.2 \%)$ than the source, attributed to the relatively large fractionation factor between Grt and $\mathrm{Cpx}\left(\Delta^{44 / 40} \mathrm{Ca}_{\mathrm{Grt}-\mathrm{Cpx}}=0.57 \times 10^{6} / \mathrm{T}^{2}\right)$ (Kang et al., 2019; Wang et al., 2019; Huang et al., 2019; Chen et al., 2020b). However, the $(\mathrm{Dy} / \mathrm{Yb})_{\mathrm{N}}$ of the Lutao volcanics show a narrow range of between 0.95 and 1.20, indicating Grt and jadeite-rich $\mathrm{Cpx}$, which are rich in heavier Ca isotopes, are absent in the petrogenesis of Lutao volcanics (He et al., 2017; Wang et al., 2019). Furthermore, Chen et al. (2020b) argued that partial melting of eclogite could not significantly fractionate $\mathrm{Ca}$ isotopes by evaluating the influences of pressure and compositions. (3) At given fractionation factors between minerals and melts, all the proposed partial melting models would generate almost constant $\delta^{44 / 40} \mathrm{Ca}$ of the melt with increasing degrees of partial melting (Chen et al., 2019, 2020b; Zhu et al., 2020a). Therefore, partial melting may have lowered the $\delta^{44 / 40} \mathrm{Ca}$ values by a limited degree $\left(<0.08 \%\right.$ with respect to BSE), such a process could not explain the $\sim 0.25 \%{ }^{44 / 40} \mathrm{Ca}$ variation of the arc magmas in this study.

\subsection{Subduction-related metasomatism}

The significant enrichment of LILEs and LREEs indicate the Lutao arc magmas are evolved from DMM metasomatized by enriched components (e.g., aqueous fluids derived from subducted SCS slab and/or sediment melt) (McDermott et al., 1993; Fourcade et al., 1994). In addition to source contamination, whole rock Nd - Hf isotopes and zircon Hf isotope results suggest the NLA volcanics may have been contaminated by continental crust materials (Yang, 1992; Lai et al., 2018). DMM is depleted by 2-3\% melt extraction with respect to the primitive mantle or BSE (Workman and Hart, 2005). Such a low degree of melt extraction would produce negligible Ca isotope fractionation (Kang et al., 2017; Chen et al., 2019). Therefore, the $\delta^{44 / 40} \mathrm{Ca}$ value of DMM should inherit the $\mathrm{Ca}$ isotopic composition of BSE $(0.94 \pm 0.05 \%)$. 
On the other hand, both source and crustal contamination would affect the $\mathrm{Sr}-\mathrm{Nd}$ and $\mathrm{Ca}$ isotopes of the generated magma, attributed to the isotopic contrast between different Earth's reservoirs. The Sr-Nd isotopic compositions of the arc magmas in this study (Fig. S5) fall within the Sr-Nd isotopic ranges of NLA volcanics reported by Lai et al. (2017) and McDermott et al. (1993). The correlation between ${ }^{143} \mathrm{Nd} /{ }^{144} \mathrm{Nd}$ and ${ }^{87} \mathrm{Sr} /{ }^{86} \mathrm{Sr}$ cannot be explained by the simple mixing between DMM and SCS sediment (Site 1144, Wei et al., 2004) or upper continental crust (UCC; Rudnick and Gao, 2003) with Sr-Nd isotopic characteristics identical to global subducting sediment (GLOSS-II; Plank, 2014) (Fig. S5). Instead, DMM may have been firstly metasomatized by slab-derived fluids (McDermott et al., 1993). Although the exact nature of slab-derived fluids is hard to be determined, the metasomatism by the subduction fluid may have lowered the ${ }^{143} \mathrm{Nd} /{ }^{144} \mathrm{Nd}$ values but little changed the ${ }^{87} \mathrm{Sr} /{ }^{86} \mathrm{Sr}$ ratios (McDermott et al., 1993). Subsequently, the melting DMM metasomatized by slab-derived fluids (the product is denoted as AMMF) was further metasomatized by sediment melts or contaminated by continental crustal materials (Yang, 1992; McDermott et al., 1993; Lai et al., 2017). Using the Sr-Nd isotopic compositions of the most depleted Lutao volcanics as the endmember Sr-Nd isotopes of AMMF (which are essentially close to the proposed Sr-Nd isotopic compositions of slab-derived fluids by (McDermott et al., 1993), most of the Lutao arc magmas follow the mixing lines between AMMF and SCS sediment/ UCC (Fig. S5), further testifying the essential role of slab-derived fluids in the petrogenesis of Lutao volcanic rocks. Nevertheless, the contributions of subducted SCS sediment and continental crustal materials are hard to be distinguished from Fig. S5, since both sources present similar Sr-Nd chemical and isotopic compositions (Rudnick and Gao, 2003; Wei et al., 2004).

Subduction fluids are dominantly derived from AOC and probably additionally released from subducted sediment at shallow subduction depth (Stern, 2002; Ribeiro et al., 2013). The carbonate solubility could reach up to $5000 \mathrm{ppm}$ at sub-arc depth in the slab-derived fluids (Kelemen and Manning, 2015). Several works suggested the prograde metamorphism dehydration and the alteration of oceanic crust may not significantly modify the $\delta^{44 / 40} \mathrm{Ca}$ values (Ionov et al., 2019; Lu et al., 2020; Wang et al., 2021). However, hydrothermal or seawater altered rock samples generally show higher $\delta^{44 / 40} \mathrm{Ca}$ values than the less-altered counterparts, despite the large $\delta^{44 / 40} \mathrm{Ca}$ ranges of AOC (Blättler and Higgins, 2017; Chen et al., 2020a). In addition, previous studies also illustrated that the fluids expelled from the subducted slab are enriched in heavier Ca isotopes with respect to the oceanic crust (John et al., 2012; Chen et al., 2018). Here, the $\delta^{44 / 40}$ Ca values of Lutao arc magmas decrease with both increasing ${ }^{87} \mathrm{Sr} /{ }^{86} \mathrm{Sr}$ and decreasing ${ }^{143} \mathrm{Nd} /{ }^{144} \mathrm{Nd}$ ratios (Fig. 6). When extrapolating the linear relationships between $\delta^{44 / 40} \mathrm{Ca}$ and $\mathrm{Sr}-\mathrm{Nd}$ isotopes to the assigned $\mathrm{Sr}-\mathrm{Nd}$ isotopes of AMMF, both correlations generate an identical endmember 
$\delta^{44 / 40} \mathrm{Ca}$ value of $\sim 1.0 \%$ for AMMF. Despite the low correlation coefficients, the monotonic variations of $\delta^{44 / 40} \mathrm{Ca}$ with $\mathrm{Sr}-\mathrm{Nd}$ isotopes and the identical endmember $\delta^{44 / 40} \mathrm{Ca}$ values for AMMF suggest this extrapolation is applicable. The estimated endmember $\delta^{44 / 40} \mathrm{Ca}$ value of AMMF falls in the Ca isotopic range of BSE, suggesting the metasomatism by slab-derived fluids may not significantly modify the Ca isotopic characteristics. This result is consistent with previous works demonstrating the $\mathrm{Ca}$ isotopic characteristics are rarely affected by carbonates released from AOC (Wang et al., 2021; Kang et al., 2021). After the metasomatism by slab-derived fluids, either the metasomatism by sediment melts or crustal contamination, or a combination of both, decreased the $\delta^{44 / 40} \mathrm{Ca}$ of Lutao arc magmas from BSE-like to MORB-like. Simultaneously, this process increased the ${ }^{87} \mathrm{Sr} /{ }^{86} \mathrm{Sr}$ and decreased the ${ }^{143} \mathrm{Nd} /{ }^{144} \mathrm{Nd}$ ratios of Lutao volcanics (Fig. 6).

In addition to $\mathrm{Sr}-\mathrm{Nd}$ isotopes, the influence of slab-derived fluids and sediment melts could be further evaluated by subduction indicators. During subduction, $\mathrm{Ba}, \mathrm{Cs}$, and $\mathrm{Sr}$ are mobilized in both slab-derived fluids and sediment melts (McCulloch and Gamble, 1991; Pearce et al., 2005), whereas Th and La can only be mobilized with sediment melts (Johnson and Plank, 1999; Spandler et al., 2007). Nb, Yb, and Sm are typical immobile element in slab-derived fluids and sediment melts (Pearce et al., 2005). Therefore, $\mathrm{Ba} / \mathrm{Nb}$ and $\mathrm{Sr} / \mathrm{Nb}$ ratios could be used to track the total subduction component. The arc magmas usually inherit the $\mathrm{Th}, \mathrm{La}$, and $\mathrm{Nb}$ anomalies of subducted sediments, making the $\mathrm{Th} / \mathrm{La}$ and $\mathrm{Nb} / \mathrm{La}$ ratios good indicators of recycling sediment (Plank, 2005, 2014). In addition, $\mathrm{Ce} / \mathrm{Pb}$ is a widely used indicator of slab-derived fluids because $\mathrm{Ce}$ and $\mathrm{Pb}$ show similar incompatibilities during partial melting but different fluid mobilities (Johnson and Plank, 1999).

The $\delta^{44 / 40} \mathrm{Ca}$ values of Lutao arc magmas show significant correlations with subduction indicators including $\mathrm{Ba} / \mathrm{Nb}, \mathrm{Ce} / \mathrm{Pb}, \mathrm{Sr} / \mathrm{Nb}$, and $\mathrm{Nb} / \mathrm{La}$ ratios (Fig. 7). The decreasing $\mathrm{Ce} / \mathrm{Pb}$ ratios in Lutao volcanics with respect to DMM could be well explained by the metasomatism by subduction fluids, because $\mathrm{Ce} / \mathrm{Pb}$ ratios are typically low in fluid-affected rock samples (Johnson and Plank, 1999). The $\delta^{44 / 40} \mathrm{Ca}$ values, however, increase significantly with $\mathrm{Ba} / \mathrm{Nb}$ and $\mathrm{Sr} / \mathrm{Nb}$ ratios, contradicting the fact that the addition of crustal materials would enrich the arc magma with lighter $\mathrm{Ca}$ isotopes (Fig. 6). In addition, the $\mathrm{Ba} / \mathrm{Nb}, \mathrm{Sr} / \mathrm{Nb}$, and $\mathrm{Nb} / \mathrm{La}$ ratios exceed the typical ranges of DMM (both global MORB and DMM show similar ranges for these ratios) and the recycled SCS sediment/UCC (Wei et al., 2004; Liu, 2020), and therefore cannot be illustrated by the simple mixing between DMM and sediment melts/continental crust materials.

This conundrum could be again reconciled by the metasomatism of DMM by slab-derived fluids before metasomatism by sediment melts and/or contamination by continental crustal materials. In this study, the arc 
magmas from Lutao, NLA present significant linear correlations between trace elemental contents and ${ }^{87} \mathrm{Sr} /{ }^{86} \mathrm{Sr}$ ratios (Fig. S6). Using the proposed Sr-Nd isotopic compositions of AMMF, we estimated the endmember chemical compositions of AMMF (Fig. S6, Table S4). The calculated results manifest fluid-mobile elements (e.g., $\mathrm{Ba}, \mathrm{Sr}$, and $\mathrm{Pb}$ ) that enriched in the subduction fluids have significantly elevated the $\mathrm{Ba} / \mathrm{Nb}, \mathrm{Sr} / \mathrm{Nb}$, and $\mathrm{Ba} / \mathrm{La}$ ratios of the arc magma. By contrast, the metasomatism of slab-derived fluids have dramatically decreased the $\mathrm{Ce} / \mathrm{Pb}$ ratios of the arc magma. Subsequently, the sediment melts formed at deep subduction depth were migrated into the magma source. Due to the chemical contrasts between recycled sediments and AMMF, this process simultaneously decreased the $\delta^{44 / 40} \mathrm{Ca}$ values and the $\mathrm{Ba} / \mathrm{Nb}, \mathrm{Ce} / \mathrm{Pb}, \mathrm{Sr} / \mathrm{Nb}$ ratios, and elevated the $\mathrm{Nb} / \mathrm{La}$ ratios of the Lutao magma (Fig. 7). Although sediment melting experiments demonstrate that the mobility and compatibility of some elements (e.g., Ba, Th, and Sr) could change significantly when temperature increases through the melting solidus (Johnson and Plank, 1999), the monotonic variations of $\delta^{44 / 40} \mathrm{Ca}$ values with these geochemical indicators demonstrate the $\mathrm{Ca}$ isotopic characteristics of Lutao arc magma have been significantly modified by the metasomatism of sediment melts. Using the estimated chemical compositions of AMMF (Fig. S6, Table S4) and the average chemical contents of SCS sediment (Wei et al., 2004), the variations of $\delta^{44 / 40} \mathrm{Ca}$ values with most geochemical indicators $\left(\mathrm{Ba} / \mathrm{Nb}, \mathrm{Sr} / \mathrm{Nb}, \mathrm{Nb} / \mathrm{La},{ }^{87} \mathrm{Sr} /{ }^{86} \mathrm{Sr}\right.$, and $\left.{ }^{143} \mathrm{Nd} /{ }^{144} \mathrm{Nd}\right)$ could be explained by the mixing between AMMF with a $\delta^{44 / 40} \mathrm{Ca}$ of $1.0 \%$ and SCS sediment with a $\delta^{44 / 40} \mathrm{Ca}$ of $-0.2-0.36 \%$ and a contribution of $<30 \%$ (Fig. 6 and Fig. 7). This Ca isotopic range for SCS sediment is reasonable because the average $\delta^{44 / 40} \mathrm{Ca}$ value of carbonate-rich sediment in Lesser Antilles is $0.36 \%$ and the $\delta^{44 / 40} \mathrm{Ca}$ of sedimentary carbonate could be as low as -1.0\%o (Fantle and Tipper, 2014). In addition, both illustrations (Fig. 6 and Fig. 7) suggest a $10-20 \%$ contribution of sediment melts into AMMF is required to transfer the Ca isotopes of Lutao arc magmas from BSElike to MORB-like, suggesting the modeling is reliable. Because the $\delta^{44 / 40} \mathrm{Ca}$ value of UCC $(\sim 0.72 \%$ ) is relatively close to the range of BSE (Kang et al., 2017; Wang et al., 2019), contamination by continental crustal materials is unlikely a dominant factor in controlling the $\mathrm{Ca}$ isotopic characteristics of Lutao arc magmas. This statement is favored by the fact that measurable $\delta^{44 / 40} \mathrm{Ca}$ variation can only be generated when the arc magma has experienced $>75 \%$ crustal contamination (Fig. 7), which is far exceeding the previously suggested ranges (<5\%, Yang, 1992; Fourcade et al., 1994; Lai et al., 2017).

\subsection{Implications for carbonate recycling in subduction zones}

The recycling of carbonate has been proposed to illustrate the $\mathrm{Ca}$ isotopic anomalies in mantle-derived basalts and carbonatites (Huang et al., 2011; Liu et al., 2017; Amsellem et al., 2020). However, only limited data have 
been reported for the Ca isotopic compositions of arc magmas and BABBs, all of which show MORB-like $\delta^{44 / 40} \mathrm{Ca}$ values and insignificant correlations with subduction indicators (Zhu et al., 2020a; Wang et al., 2021; Kang et al., 2021). The reported BABBs collected from the southwestern Pacific show narrow $\delta^{44 / 40}$ Ca values with an average of $0.80 \pm 0.08 \%$ ( $2 \mathrm{SD}, \mathrm{n}=21)$ (Zhu et al., 2020a). Arc magmas generally receive higher influence of subduction fluids than BABBs. The arc volcanics collected from Tonga, Mariana, Central America, Southern Lesser Antilles, and central-eastern Aleutian Arcs, however, mostly exhibit $\delta^{44 / 40} \mathrm{Ca}$ in a narrow range of $0.78-0.86 \%$ with an average of $0.83 \pm 0.12 \%$ (2SD, n=61) (Wang et al., 2021; Kang et al., 2021). Despite strong evidence of fluidmediated carbonate transfer in these arcs, the MORB-like $\delta^{44 / 40} \mathrm{Ca}$ signals in these rocks are dominantly controlled by the effect of mantle partial melting.

In this study, by contrast, the Lutao volcanics from NLA present both BSE-like and MORB-like Ca isotopic compositions (Table 1). As we have stated in section 5.3, partial melting would only produce $\delta^{44 / 40}$ Ca offsets with respect to BSE, while the generated melt should show almost constant Ca isotopes at different degrees of partial melting (Zhang et al., 2018; Chen et al., 2019; Zhu et al., 2020a). Therefore, the BSE-like $\delta^{44 / 40}$ Ca values of some Lutao volcanics suggest either the arc magma has experienced partial melting with low fractionation factor between Opx and Cpx (e.g., at $\alpha_{\mathrm{Opx}-\mathrm{Cpx}}$ of 1.00026 , the $\delta^{44 / 40} \mathrm{Ca}$ of partial melt would be only $\sim 0.04 \%$ lower than the starting peridotite) (Chen et al., 2019), or the MORB-like Ca isotopes of partial melts have been slightly elevated by the metasomatism of slab-derived fluids. Both mechanisms are plausible because most of the carbonate in the slab-derived fluids are expelled from AOC, while the average $\delta^{44 / 40} \mathrm{Ca}$ of AOC $(1.03 \pm 0.35 \%$, (Blättler and Higgins, 2017; Chen et al., 2020a; Kang et al., 2021) is slightly higher than that of BSE. Nevertheless, as illustrated by Kang et al. (2021), the Ca isotopes of mantle wedge would be largely unchanged by the addition of AOC carbonate. This result is also observed for the Lutao arc magmas that their Ca isotopic characteristics are remained at BSE level during the metasomatism by slab-derived fluids (Fig. 6, Fig. 7).

The $\delta^{44 / 40} \mathrm{Ca}$ of Lutao volcanics decreases significantly with subduction indicators, suggesting the metasomatism by sediment melts did affect the Ca isotopes of arc magmas. Such an effect, however, was absent in the reported BABBs and arc magmas (Zhu et al., 2020a; Wang et al., 2021; Kang et al., 2021). Because both clay-rich sediments and AOC generally present $\delta^{44 / 40} \mathrm{Ca}$ values similar to BSE (Blättler and Higgins, 2017; Zhu et al., 2020c), sedimentary carbonate should play a decisive role in regulating the $\mathrm{Ca}$ isotopic characteristics of arc magmas. Therefore, the absence of carbonate $\mathrm{Ca}$ isotope signal in these studies is induced by the limited budget of sedimentary Ca recycled into the arc magmas, possibly attributed to the low carbonate contents in the clay-rich 
sediments (Plank and Langmuir, 1998; Plank, 2014; Zhu et al., 2020a), or the survival of subducted carbonate during plate subduction (Plank and Langmuir, 1993; Shen et al., 2018; Kang et al., 2021). The arc magmas from these studies present $\mathrm{Sr}-\mathrm{Nd}$ isotopes and subduction indicators (e.g., $\mathrm{Ba} / \mathrm{Nb}$ and $\mathrm{Nb} / \mathrm{La}$ ) close to DMM ranges, further supporting the relatively low influence of subducting sediment (Zhu et al., 2020a; Wang et al., 2021; Kang et al., 2021). By contrast, the Lutao volcanics demonstrate Sr-Nd isotopes and subduction indicators away from the DMM values, suggesting the Lutao magma should have received higher proportions of subduction materials than these previously reported BABBs and arc magmas (Fig. 6 and 7).

Here, we roughly estimate the fluxes of sedimentary Ca subducted into global trenches using the published values on subduction rate, thickness and bulk density, bulk $\mathrm{CaO}$ and carbonate contents in the subducted sediments (Table S5; Wei et al., 2004; Scholl and von Huene, 2007; Syracuse et al., 2010; Plank, 2014). The limited sedimentary Ca fluxes in Southern Lesser Antilles, Mariana, Tonga, and Aleutian arcs well explain the absence of sedimentary Ca isotope signals in the corresponding arc magmas and BABBs (Zhu et al., 2020a; Wang et al., 2021; Kang et al., 2021). The sedimentary Ca fluxes and total Ca fluxes in Central America and Manila trenches are orders of magnitude higher than other trenches due to their high carbonate contents in the subducting sediments (Plank, 2014). However, according to the Sr chemical and isotopic compositions of the subducted sediments in both trenches, the Lutao arc magmas should have received higher proportions of subduction materials with respect to the arc magmas from Central America (Wei et al., 2004; Plank, 2014). Therefore, higher proportions of subducted carbonate in the Central America should have been survived beyond the arc depth during plate subduction. This phenomenon is possibly related to the thermal structures of subduction zones. According to Syracuse et al. (2010), the slab temperature beneath the arc of Central America (represented by Costa Rica) is 690 ${ }^{\circ} \mathrm{C}$ (D80 model), much lower than that of North Philippines $\left(833{ }^{\circ} \mathrm{C}\right)$. The temperature and pressure condition of the slab underneath the Central America arc is close to but fall out of the solidus of $\mathrm{H}_{2} \mathrm{O}$-saturated sediment melting at 2.5 - 3.2 $\mathrm{GPa}$ and $670-950{ }^{\circ} \mathrm{C}$ (Keken et al., 2011). By contrast, the temperature and pressure condition of the NLA slab (represented by North Philippines) allow the $\mathrm{H}_{2} \mathrm{O}$-saturated sediment melting (Fig. 8). Therefore, the subducting sediment beneath NLA should have experienced higher degree of melting and induced more intensive metasomatism of sediment melts than that beneath the Central America Arc. Because chemical signatures of subducted sediments are predominantly preserved in the sediment melts rather than subduction fluids (Kawamoto et al., 2012), the limited sediment melting in Central America suggests most of the subducted carbonate is retained on the descending slab. The lower carbonate recycling efficiency in Central America with respect to NLA is 
evidenced by the decarbonation efficiency, where the Philippines exhibit dramatically higher carbon recycling efficiency than Central America (Johnston et al., 2011).

The melting of subducting sediments during plate subduction is critical for regulating the budget of subducted carbonate recycling back to the arc. The fluxes of sedimentary Ca subducted into global trenches are predominantly constrained by the carbonate contents in the subducting sediments (Table S5). Large fluxes of sedimentary Ca only occur in the trenches with abundant carbonate-rich sediments (e.g., Central America, Sunda, Izu-Bonin, New Zealand, North Philippines/Manila, and South America). However, much of the subducted sedimentary carbonate would be survived during plate subduction and enters the deep mantle if the subducting sediment experienced limited sediment melting at arc depth. Therefore, carbonate Ca isotopic signals may could only be observed in the arcs with both high sedimentary $\mathrm{Ca}$ fluxes and temperature-pressure conditions well beyond the solidus of $\mathrm{H}_{2} \mathrm{O}$ saturated sediment melting, e.g., NLA, Nicaragua, Guatemala, Andes (Colombia, Peru, and South Chile), North Vanuatu, New Zealand, and Kermadec (Fig. 8). Sediment melting in these subduction zones could recycle part of sedimentary carbonate into the arc magmas. The rest part, possibly the major part of sedimentary carbonate would be carried by the downgoing slab and enter the deep mantle.

\section{Conclusions}

The arc magmas from Lutao island, NLA present significant enrichment of LILEs with respect to HFSEs and LREEs over HREEs, ascribed to the subduction-related metasomatism of arc magma evolved from partial melting of DMM. The Lutao volcanics show both BSE-like and MORB-like large $\delta^{44 / 40} \mathrm{Ca}$ values varying from $0.76 \pm$ $0.04 \%$ to $1.01 \pm 0.03 \%$. Both secondary alteration and fractional crystallization during magma cooling are not responsible for the range and variation of $\mathrm{Ca}$ isotopic compositions. Although partial melting may have decreased the initial $\delta^{44 / 40} \mathrm{Ca}$ values by a limited degree, this process could not explain the large variation of $\delta^{44 / 40} \mathrm{Ca}$ values. Instead, the $\mathrm{Ca}$ isotopic characteristics of the Lutao arc magmas are dominantly controlled by the subductionrelated metasomatism (Fig. 9). The melting of DMM was firstly metasomatized by slab-derived fluids at shallow depth, which process changed the $\delta^{44 / 40} \mathrm{Ca}$ values by a negligible extent but dramatically enriched the magma with fluid-mobile elements (e.g., $\mathrm{Ba}, \mathrm{Sr}$, and $\mathrm{Pb}$ ). Then, the arc magma was metasomatized by sediment melts by different degrees, evidenced by the significant correlations between $\delta^{44 / 40} \mathrm{Ca}$ values and $\mathrm{Sr}-\mathrm{Nd}$ isotopic compositions and subduction indicators (e.g., $\mathrm{Ba} / \mathrm{Nb}, \mathrm{Sr} / \mathrm{Nb}$ and $\mathrm{Nb} / \mathrm{La}$ ratios). Our findings contradict with previous works on BABBs and arc magmas, where they reported $\delta^{44 / 40} \mathrm{Ca}$ values dominantly determined by mantle 
partial melting. The absence of carbonate $\mathrm{Ca}$ isotopic signals in these studies is attributed to either low flux of sedimentary $\mathrm{Ca}$ in the subducting sediments (e.g., Tonga, Mariana, and Aleutians), or the thermal structures of subduction zones only allow limited degree of sediment melting beneath the arc (e.g., Costa Rica). Under such situations, most of the subducted sedimentary carbonate would be survived beyond the sub-arc and enter the deep mantle to result in $\mathrm{Ca}$ isotopic heterogeneity.

\section{Acknowledgments}

The authors thank Prof. Tsanyao Frank Yang for collecting the samples and Prof. Li-Hong Lin for providing the samples. We acknowledge the use of EPMA in the Key Laboratory of Submarine Geosciences, State Oceanic Administration, Second Institute of Oceanography, Ministry of Natural Resources. This work was financially supported by the National Natural Science Foundation of China (grant No. 41806051).

Data associated with this study have been listed in the tables. Additional data can be obtained from the supplementary material and by contacting the corresponding author (chenxg83@zju.edu.cn).

\section{Conflict of interest}

The authors declare no conflict of interest.

\section{References}

Amini M., Eisenhauer A., Böhm F., Fietzke J., Bach W., Garbe-Schönberg D., Rosner M., Bock B., Lackschewitz K. S. and Hauff F. (2008) Calcium isotope $\left(\delta^{44 / 40} \mathrm{Ca}\right)$ fractionation along hydrothermal pathways, Logatchev field (Mid-Atlantic Ridge, $14^{\circ} 45^{\prime} \mathrm{N}$ ). Geochim. Cosmochim. Acta 72, 4107-4122.

Amini M., Eisenhauer A., Böhm F., Holmden C., Kreissig K., Hauff F. and Jochum K. P. (2009) Calcium Isotopes $\left({ }^{844 / 40} \mathrm{Ca}\right)$ in MPI-DING Reference Glasses, USGS Rock Powders and Various Rocks: Evidence for Ca Isotope Fractionation in Terrestrial Silicates. Geostand. Geoanalytical Res. 33, 231-247.

Amsellem E., Moynier F., Bertrand H., Bouyon A., Mata J., Tappe S. and Day J. M. D. (2020) Calcium isotopic evidence for the mantle sources of carbonatites. Sci. Adv. 6, eaba3269.

Amsellem E., Moynier F., Pringle E. A., Bouvier A., Chen H. and Day J. M. D. (2017) Testing the chondrule-rich accretion model for planetary embryos using calcium isotopes. Earth Planet. Sci. Lett. 469, 75-83.

Amsellem E., Moynier F. and Puchtel I. S. (2019) Evolution of the Ca isotopic composition of the mantle. Geochim. Cosmochim. Acta 258, 195-206. 
Antonelli M. A. and Simon J. I. (2020) Calcium isotopes in high-temperature terrestrial processes. Chem. Geol. 548, 119651 .

Banerjee A. and Chakrabarti R. (2019) A geochemical and Nd, Sr and stable Ca isotopic study of carbonatites and associated silicate rocks from the $\sim 65 \mathrm{Ma}$ old Ambadongar carbonatite complex and the Phenai Mata igneous complex, Gujarat, India: Implications for crustal contamination, carbonate recycling, hydrothermal alteration and source-mantle mineralogy. Lithos 326-327, 572-585.

Banerjee A. and Chakrabarti R. (2018) Large Ca stable isotopic $\left(\delta^{44 / 40} \mathrm{Ca}\right)$ variation in a hand-specimen sized spheroidally weathered diabase due to selective weathering of clinopyroxene and plagioclase. Chem. Geol. 483, 295-303.

Biq C. (1971) Dual-trench structure in the Taiwan-Luzon region. Proc. Geol. Soc. China 15, 65-75.

Blättler C. L. and Higgins J. A. (2017) Testing Urey's carbonate-silicate cycle using the calcium isotopic composition of sedimentary carbonates. Earth Planet. Sci. Lett. 479, 241-251.

Bowin C., Lu R. S., Lee C.-S. and Schouten H. (1978) Plate Convergence and Accretion in Taiwan-Luzon Region. AAPG Bull. 62, 1645-1672.

Chacko T., Cole D. R. and Horita J. (2001) Equilibrium Oxygen, Hydrogen and Carbon Isotope Fractionation Factors Applicable to Geologic Systems. Rev. Mineral. Geochem. 43, 1-81.

Chen C., Ciazela J., Li W., Dai W., Wang Z., Foley S. F., Li M., Hu Z. and Liu Y. (2020a) Calcium isotopic compositions of oceanic crust at various spreading rates. Geochim. Cosmochim. Acta 278, 272-288.

Chen C., Dai W., Wang Z., Liu Y., Li M., Becker H. and Foley S. F. (2019) Calcium isotope fractionation during magmatic processes in the upper mantle. Geochim. Cosmochim. Acta 249, 121-137.

Chen C. H., Liu T. K., Yang T. Y. and Chen Y. G. (1994) Lutao: Explanatory text of the geologic map of Taiwan (in Chinese). Cent. Geol. Surv. 57pp.

Chen C., Huang J.-X., Foley S. F., Wang Z., Moynier F., Liu Y., Dai W. and Li M. (2020b) Compositional and pressure controls on calcium and magnesium isotope fractionation in magmatic systems. Geochim. Cosmochim. Acta 290, 257-270.

Chen C., Liu Y., Feng L., Foley S. F., Zhou L., Ducea M. N. and Hu Z. (2018) Calcium isotope evidence for subduction-enriched lithospheric mantle under the northern North China Craton. Geochim. Cosmochim. Acta 238, 55-67.

Chen C.-H. (1986) Petrology and genesis of cognate plutonic inclusions in andesites of East Coastal Range, Lutao and Lanhsu, Taiwan. Mem Geol Soc China 7, 259-281.

Chen Chang-Hwa, Shieh Y.-N., Lee T., Chen Cheng-Hong and Mertzman S. A. (1990) Nd-Sr-O isotopic evidence for source contamination and an unusual mantle component under Luzon Arc. Geochim. Cosmochim. Acta 54, 2473-2483.

Chen J. and Lin F. (1980) Geochemistry of Lutao andesites. Acta Ocean. Taiwanica 11, 49-69.

Dai W., Wang Z., Liu Y., Chen C., Zong K., Zhou L., Zhang G., Li M., Moynier F. and Hu Z. (2020) Calcium isotope compositions of mantle pyroxenites. Geochim. Cosmochim. Acta 270, 144-159.

DePaolo D. J. (2004) Calcium Isotopic Variations Produced by Biological, Kinetic, Radiogenic and Nucleosynthetic Processes. Rev. Mineral. Geochem. 55, 255-288. 
Fantle M. S. and DePaolo D. J. (2005) Variations in the marine Ca cycle over the past 20 million years. Earth Planet. Sci. Lett. 237, 102-117.

Fantle M. S. and Tipper E. T. (2014) Calcium isotopes in the global biogeochemical Ca cycle: Implications for development of a Ca isotope proxy. Earth-Sci. Rev. 129, 148-177.

Farkaš J., Buhl D., Blenkinsop J. and Veizer J. (2007) Evolution of the oceanic calcium cycle during the late Mesozoic: Evidence from $\delta^{44 / 40} \mathrm{Ca}$ of marine skeletal carbonates. Earth Planet. Sci. Lett. 253, 96-111.

Farkaš J., Déjeant A., Novák M. and Jacobsen S. B. (2011) Calcium isotope constraints on the uptake and sources of $\mathrm{Ca}^{2+}$ in a base-poor forest: a new concept of combining stable $\left(\delta^{44 / 42} \mathrm{Ca}\right)$ and radiogenic $(\varepsilon \mathrm{Ca})$ signals. Geochim. Cosmochim. Acta 75, 7031-7046.

Feng C., Qin T., Huang S., Wu Z. and Huang F. (2014) First-principles investigations of equilibrium calcium isotope fractionation between clinopyroxene and Ca-doped orthopyroxene. Geochim. Cosmochim. Acta 143, 132-142.

Feng L., Lian Z., Lu Y., Wen Z., Qian W., Tong S. and Hu Z. (2018) A rapid and simple single-stage method for Ca separation from geological and biological samples for isotopic analysis by MC-ICP-MS. J. Anal. At. Spectrom. 33, 413-421.

Feng L., Zhou L., Yang L., DePaolo D. J., Tong S.-Y., Liu Y.-S., Owens T. L. and Gao S. (2017) Calcium Isotopic Compositions of Sixteen USGS Reference Materials. Geostand. Geoanalytical Res. 41, 93-106.

Fourcade S., Maury R. C., Defant M. J. and McDermott F. (1994) Mantle metasomatic enrichment versus arc crust contamination in the Philippines: Oxygen isotope study of Batan ultramafic nodules and northern Luzon arc lavas. Chem. Geol. 114, 199-215.

Green D. H. (1973) Experimental melting studies on a model upper mantle composition at high pressure under water-saturated and water-undersaturated conditions. Earth Planet. Sci. Lett. 19, 37-53.

Gussone N., Austrheim H., Westhues A. and Mezger K. (2020) Origin of Rodingite Forming Fluids Constrained by Calcium and Strontium Isotope Ratios in the Leka Ophiolite Complex. Chem. Geol. 542, 119598.

Gussone N., Böhm F., Eisenhauer A., Dietzel M., Heuser A., Teichert B. M. A., Reitner J., Wörheide G. and Dullo W.-C. (2005) Calcium isotope fractionation in calcite and aragonite. Geochim. Cosmochim. Acta 69 , 4485-4494.

Gussone N., Schmitt A.-D., Heuser A., Wombacher F., Dietzel M., Tipper E. and Schiller M. (2016) Calcium Stable Isotope Geochemistry., Springer Berlin Heidelberg, Berlin, Heidelberg.

He Y., Wang Y., Zhu C., Huang S. and Li S. (2017) Mass-Independent and Mass-Dependent Ca Isotopic Compositions of Thirteen Geological Reference Materials Measured by Thermal Ionisation Mass Spectrometry. Geostand. Geoanalytical Res. 41, 283-302.

Heuser A. (2016) Biomedical application of Ca stable isotopes. In Calcium stable isotope geochemistry. Springer. pp. 247-260.

Heuser A. and Eisenhauer A. (2008) The Calcium Isotope Composition $\left(\delta^{44 / 40} \mathrm{Ca}\right)$ of NIST SRM $915 \mathrm{~b}$ and NIST SRM 1486. Geostand. Geoanalytical Res. 32, 311-315.

Ho C. S. (1986) A synthesis of the geologic evolution of Taiwan. Tectonophysics 125, 1-16. 
Huang F., Zhou C., Wang W., Kang J. and Wu Z. (2019) First-principles calculations of equilibrium Ca isotope fractionation: Implications for oldhamite formation and evolution of lunar magma ocean. Earth Planet. Sci. Lett. 510, 153-160.

Huang S., Farkaš J. and Jacobsen S. B. (2010) Calcium isotopic fractionation between clinopyroxene and orthopyroxene from mantle peridotites. Earth Planet. Sci. Lett. 292, 337-344.

Huang S., Farkaš J. and Jacobsen S. B. (2011) Stable calcium isotopic compositions of Hawaiian shield lavas: Evidence for recycling of ancient marine carbonates into the mantle. Geochim. Cosmochim. Acta $\mathbf{7 5}$, 4987-4997.

Huang S. and Jacobsen S. B. (2017) Calcium isotopic compositions of chondrites. Geochim. Cosmochim. Acta 201, 364-376.

Ionov D. A., Qi Y.-H., Kang J.-T., Golovin A. V., Oleinikov O. B., Zheng W., Anbar A. D., Zhang Z.-F. and Huang F. (2019) Calcium isotopic signatures of carbonatite and silicate metasomatism, melt percolation and crustal recycling in the lithospheric mantle. Geochim. Cosmochim. Acta 248, 1-13.

Jacobson A. D., Grace Andrews M., Lehn G. O. and Holmden C. (2015) Silicate versus carbonate weathering in Iceland: New insights from Ca isotopes. Earth Planet. Sci. Lett. 416, 132-142.

Jaques A. L. and Green D. H. (1980) Anhydrous melting of peridotite at 0-15 Kb pressure and the genesis of tholeiitic basalts. Contrib. Mineral. Petrol. 73, 287-310.

Jochum K. P. and Verma S. P. (1996) Extreme enrichment of Sb, Tl and other trace elements in altered MORB. Chem. Geol. 130, 289-299.

John T., Gussone N., Podladchikov Y. Y., Bebout G. E., Dohmen R., Halama R., Klemd R., Magna T. and Seitz H.-M. (2012) Volcanic arcs fed by rapid pulsed fluid flow through subducting slabs. Nat. Geosci. 5, 489492.

Johnson M. C. and Plank T. (1999) Dehydration and melting experiments constrain the fate of subducted sediments. Geochem. Geophys. Geosystems 1, 1007.

Johnston F. K. B., Turchyn A. V. and Edmonds M. (2011) Decarbonation efficiency in subduction zones: Implications for warm Cretaceous climates. Earth Planet. Sci. Lett. 303, 143-152.

Juang W.-S. and Chen J.-C. (1990) Geochronology and chemical variations of volcanic rocks along the arccontinent collision zone in eastern Taiwan. Bull Nat Mus. Nat Sci, 89-118.

Kang J.-T., Ionov D. A., Liu F., Zhang C.-L., Golovin A. V., Qin L.-P., Zhang Z.-F. and Huang F. (2017) Calcium isotopic fractionation in mantle peridotites by melting and metasomatism and $\mathrm{Ca}$ isotope composition of the Bulk Silicate Earth. Earth Planet. Sci. Lett. 474, 128-137.

Kang J.-T., Ionov D. A., Zhu H.-L., Liu F., Zhang Z.-F., Liu Z. and Huang F. (2019) Calcium isotope sources and fractionation during melt-rock interaction in the lithospheric mantle: Evidence from pyroxenites, wehrlites, and eclogites. Chem. Geol. 524, 272-282.

Kang J.-T., Qi Y.-H., Li K., Bai J.-H., Yu H.-M., Zheng W., Zhang Z.-F. and Huang F. (2021) Calcium isotope compositions of arc magmas: implications for $\mathrm{Ca}$ and carbonate recycling in subduction zones. Geochim. Cosmochim. Acta 306, 1-19. 
Kang J.-T., Zhou C., Huang J.-Y., Hao Y.-T., Liu F., Zhu H.-L., Zhang Z.-F. and Huang F. (2020) Diffusiondriven $\mathrm{Ca}-\mathrm{Fe}$ isotope fractionations in the upper mantle: Implications for mantle cooling and melt infiltration. Geochim. Cosmochim. Acta 290, 41-58.

Kang J.-T., Zhu H.-L., Liu Y.-F., Liu F., Wu F., Hao Y.-T., Zhi X.-C., Zhang Z.-F. and Huang F. (2016) Calcium isotopic composition of mantle xenoliths and minerals from Eastern China. Geochim. Cosmochim. Acta 174, 335-344.

Kawamoto T., Kanzaki M., Mibe K., Matsukage K. N. and Ono S. (2012) Separation of supercritical slab-fluids to form aqueous fluid and melt components in subduction zone magmatism. Proc. Natl. Acad. Sci. 109, 18695-18700.

Keken P. E. van, Hacker B. R., Syracuse E. M. and Abers G. A. (2011) Subduction factory: 4. Depth-dependent flux of H2O from subducting slabs worldwide. J. Geophys. Res. Solid Earth 116, B01401.

Kelemen P. B. and Manning C. E. (2015) Reevaluating carbon fluxes in subduction zones, what goes down, mostly comes up. Proc. Natl. Acad. Sci. 112, E3997-E4006.

Knittel U., Defant M. J. and Raczek I. (1988) Recent enrichment in the source region of arc magmas from Luzon island, Philippines: Sr and Nd isotopic evidence. Geology 16, 73-76.

Lai Y.-M., Chu M.-F., Chen W.-S., Shao W.-Y., Lee H.-Y. and Chung S.-L. (2018) Zircon U-Pb and Hf isotopic constraints on the magmatic evolution of the Northern Luzon Arc. Terr. Atmospheric Ocean. Sci. 29, $149-186$.

Lai Y.-M., Song S.-R., Lo C.-H., Lin T.-H., Chu M.-F. and Chung S.-L. (2017) Age, geochemical and isotopic variations in volcanic rocks from the Coastal Range of Taiwan: Implications for magma generation in the Northern Luzon Arc. Lithos 272-273, 92-115.

Lan C.-Y., Shen J. J-S. and Lee T. (1986) Rb-Sr isotopic study of andesites from Lu-Tao, Lan-Hsu, and HsiaoLan-Hsu: eruption ages and isotopic heterogeneity. Bull. Inst. Earth Sci. Acad. Sin 6, 211-226.

Lin J., Liu Y., Yang Y. and Hu Z. (2016) Calibration and correction of LA-ICP-MS and LA-MC-ICP-MS analyses for element contents and isotopic ratios. Solid Earth Sci. 1, 5-27.

Liu F., Li X., Wang G., Liu Y., Zhu H., Kang J., Huang F., Sun W., Xia X. and Zhang Z. (2017) Marine Carbonate Component in the Mantle Beneath the Southeastern Tibetan Plateau: Evidence from Magnesium and Calcium Isotopes. J. Geophys. Res. Solid Earth 122, 9729-9744.

Liu X. (2020) Provenance and evolution of sediments at Site U1431 from the East Subbasin of the South China Sea. Masters, Zhejiang University.

Lo C.-H., Onstott T. C., Chen C.-H. and Lee T. (1994) An assessment of 40Ar39Ar dating for the whole-rock volcanic samples from the Luzon Arc near Taiwan. Chem. Geol. 114, 157-178.

Lu W.-N., He Y., Wang (王阳) Y. and Ke S. (2020) Behavior of calcium isotopes during continental subduction recorded in meta-basaltic rocks. Geochim. Cosmochim. Acta 278, 392-404.

Marini J.-C., Chauvel C. and Maury R. C. (2005) Hf isotope compositions of northern Luzon arc lavas suggest involvement of pelagic sediments in their source. Contrib. Mineral. Petrol. 149, 216-232.

McCulloch M. T. and Gamble J. A. (1991) Geochemical and geodynamical constraints on subduction zone magmatism. Earth Planet. Sci. Lett. 102, 358-374. 
McDermott F., Defant M. J., Hawkesworth C. J., Maury R. C. and Joron J. L. (1993) Isotope and trace element evidence for three component mixing in the genesis of the North Luzon arc lavas (Philippines). Contrib. Mineral. Petrol. 113, 9-23.

McDonough W. F. and Sun S. S. (1995) The composition of the Earth. Chem. Geol. 120, 223-253.

Mukasa S. B., McCabe R. and Gill J. B. (1987) Pb-isotopic compositions of volcanic rocks in the West and East Philippine island arcs: presence of the Dupal isotopic anomaly. Earth Planet. Sci. Lett. 84, 153-164.

Nielsen L. C., Druhan J. L., Yang W., Brown S. T. and DePaolo D. J. (2012) Calcium Isotopes as Tracers of Biogeochemical Processes. In Handbook of Environmental Isotope Geochemistry: Vol I (ed. M. Baskaran). Advances in Isotope Geochemistry. Springer, Berlin, Heidelberg. pp. 105-124.

Pearce J. A., Stern R. J., Bloomer S. H. and Fryer P. (2005) Geochemical mapping of the Mariana arc-basin system: Implications for the nature and distribution of subduction components. Geochem. Geophys. Geosystems 6, Q07006.

Perfit M. R., Gust D. A., Bence A. E., Arculus R. J. and Taylor S. R. (1980) Chemical characteristics of island-arc basalts: Implications for mantle sources. Chem. Geol. 30, 227-256.

Plank T. (2005) Constraints from Thorium/Lanthanum on Sediment Recycling at Subduction Zones and the Evolution of the Continents. J. Petrol. 46, 921-944.

Plank T. (2014) The Chemical Composition of Subducting Sediments. In Treatise on Geochemistry Elsevier. pp. $607-629$.

Plank T. and Langmuir C. H. (1998) The chemical composition of subducting sediment and its consequences for the crust and mantle. Chem. Geol. 145, 325-394.

Plank T. and Langmuir C. H. (1993) Tracing trace elements from sediment input to volcanic output at subduction zones. Nature 362, 739-743.

Plank T. and Manning C. E. (2019) Subducting carbon. Nature 574, 343-352.

Polat A. and Hofmann A. W. (2003) Alteration and geochemical patterns in the 3.7-3.8 Ga Isua greenstone belt, West Greenland. Precambrian Res. 126, 197-218.

Ribeiro J. M., Stern R. J., Kelley K. A., Martinez F., Ishizuka O., Manton W. I. and Ohara Y. (2013) Nature and distribution of slab-derived fluids and mantle sources beneath the Southeast Mariana forearc rift. Geochem. Geophys. Geosystems 14, 4585-4607.

Richard M., Bellon H., Maury R., Barrier E. and Wen-Shing J. (1986) Miocene to recent calc-alkalic volcanism in eastern Taiwan: K-Ar ages and petrography. Tectonophysics 125, 87-102.

Rudnick R. L. and Gao S. (2003) Composition of the continental crust. In The Crust. Elsevier-Pergamon, Oxford.

Scholl D. W. and von Huene R. (2007) Crustal recycling at modern subduction zones applied to the past-Issues of growth and preservation of continental basement crust, mantle geochemistry, and supercontinent reconstruction. In Geological Society of America Memoirs. Geological Society of America. pp. 9-32.

Shao W.-Y., Chung S.-L. and Chen W.-S. (2014) Zircon U-Pb Age Determination of Volcanic Eruptions in Lutao and Lanyu in the Northern Luzon Magmatic Arc. Terr. Atmospheric Ocean. Sci. 25, 149-187.

Shen J., Li S.-G., Wang S.-J., Teng F.-Z., Li Q.-L. and Liu Y.-S. (2018) Subducted Mg-rich carbonates into the deep mantle wedge. Earth Planet. Sci. Lett. 503, 118-130. 
Simon J. I. and DePaolo D. J. (2010) Stable calcium isotopic composition of meteorites and rocky planets. Earth Planet. Sci. Lett. 289, 457-466.

Skulan J., DePaolo D. J. and Owens T. L. (1997) Biological control of calcium isotopic abundances in the global calcium cycle. Geochim. Cosmochim. Acta 61, 2505-2510.

Spandler C., Mavrogenes J. and Hermann J. (2007) Experimental constraints on element mobility from subducted sediments using high-P synthetic fluid/melt inclusions. Chem. Geol. 239, 228-249.

Stern R. J. (2002) Subduction Zones. Rev. Geophys. 40, 3-1-3-38.

Sun J., Zhu X.-K., Belshaw N. S., Chen W., Doroshkevich A. G., Luo W.-J., Song W.-L., Chen B.-B., Cheng Z.G., Li Z.-H., Wang Y., Kynicky J. and Henderson G. M. (2021) Ca isotope systematics of carbonatites: Insights into carbonatite source and evolution. Geochem. Perspect. Lett. 17, 11-15.

Suppe J. (1984) Kinematics of arc-continent collision, flipping of subduction and back-arc spreading near Taiwan. Mem. Geol. Soc. China 6, 21-33.

Suppe J. (1981) Mechanics of mountain building and metamorphism in Taiwan. Mem. Geol. Soc. China 4, 67-89. Syracuse E. M., van Keken P. E. and Abers G. A. (2010) The global range of subduction zone thermal models. Phys. Earth Planet. Inter. 183, 73-90.

Tanaka T., Togashi S., Kamioka H., Amakawa H., Kagami H., Hamamoto T., Yuhara M., Orihashi Y., Yoneda S., Shimizu H., Kunimaru T., Takahashi K., Yanagi T., Nakano T., Fujimaki H., Shinjo R., Asahara Y., Tanimizu M. and Dragusanu C. (2000) JNdi-1: a neodymium isotopic reference in consistency with LaJolla neodymium. Chem. Geol. 168, 279-281.

Taylor B. and Hayes D. E. (1983) Origin and history of the South China Sea basin. In The tectonic and geologic evolution of Southeast Asian seas and islands: Part 2. Geophysical Monograph Series. Wiley Online Library. pp. 23-56.

Thirlwall M. F. (1991) Long-term reproducibility of multicollector $\mathrm{Sr}$ and $\mathrm{Nd}$ isotope ratio analysis. Chem. Geol. Isot. Geosci. Sect. 94, 85-104.

Tipper E. T., Galy A. and Bickle M. J. (2008) Calcium and magnesium isotope systematics in rivers draining the Himalaya-Tibetan-Plateau region: Lithological or fractionation control? Geochim. Cosmochim. Acta $\mathbf{7 2}$, $1057-1075$.

Valdes M. C., Debaille V., Berger J. and Armytage R. M. G. (2019) The effects of high-temperature fractional crystallization on calcium isotopic composition. Chem. Geol. 509, 77-91.

Valdes M. C., Moreira M., Foriel J. and Moynier F. (2014) The nature of Earth's building blocks as revealed by calcium isotopes. Earth Planet. Sci. Lett. 394, 135-145.

Vukadinovic D. (1993) Are Sr enrichments in arc basalts due to plagioclase accumulation? Geology 21, 611-614. Wang W., Zhou C., Qin T., Kang J.-T., Huang S., Wu Z. and Huang F. (2017) Effect of Ca content on equilibrium $\mathrm{Ca}$ isotope fractionation between orthopyroxene and clinopyroxene. Geochim. Cosmochim. Acta 219, 4456.

Wang X., Wang Z., Liu Y., Park J.-W., Kim J., Li M. and Zou Z. (2021) Calcium Stable Isotopes of Tonga and Mariana Arc Lavas: Implications for Slab Fluid-Mediated Carbonate Transfer in Cold Subduction Zones. J. Geophys. Res. Solid Earth 126, e2020JB020207. 
Wang Y. and Chung S.-H. (1991) A preliminary mineralogical study of the Lutao andesites. Spec. Publ. Cent. Geol. Surv. 5, 77-91.

Wang Y., He Y., Wu H., Zhu C., Huang S. and Huang J. (2019) Calcium isotope fractionation during crustal melting and magma differentiation: Granitoid and mineral-pair perspectives. Geochim. Cosmochim. Acta 259, 37-52.

Wei G., Liu Y., Li X., Shao L. and Fang D. (2004) Major and trace element variations of the sediments at ODP Site 1144, South China Sea, during the last $230 \mathrm{ka}$ and their paleoclimate implications. Palaeogeogr. Palaeoclimatol. Palaeoecol. 212, 331-342.

Workman R. K. and Hart S. R. (2005) Major and trace element composition of the depleted MORB mantle (DMM). Earth Planet. Sci. Lett. 231, 53-72.

Yang T. F. (1992) Magma evolution of the North Luzon arc and its tectonic implication. Ph.D., National Taiwan University.

Yang T. F., Tien J.-L., Chen C.-H., Lee T. and Punongbayan R. S. (1995) Fission-track dating of volcanics in the northern part of the Taiwan-Luzon Arc: eruption ages and evidence for crustal contamination. $J$. Southeast Asian Earth Sci. 11, 81-93.

Zhang H., Wang Y., He Y., Teng F.-Z., Jacobsen S. B., Helz R. T., Marsh B. D. and Huang S. (2018) No Measurable Calcium Isotopic Fractionation During Crystallization of Kilauea Iki Lava Lake. Geochem. Geophys. Geosystems 19, 3128-3139.

Zhang W. and Hu Z. (2020) Estimation of Isotopic Reference Values for Pure Materials and Geological Reference Materials. At. Spectrosc. 41, 93-102.

Zhao X., Zhang Z., Huang S., Liu Y., Li X. and Zhang H. (2017) Coupled extremely light Ca and Fe isotopes in peridotites. Geochim. Cosmochim. Acta 208, 368-380.

Zhu H., Du L., Li X., Zhang Z. and Sun W. (2020a) Calcium isotopic fractionation during plate subduction: Constraints from back-arc basin basalts. Geochim. Cosmochim. Acta 270, 379-393.

Zhu H., Du L., Zhang Z. and Sun W. (2020b) Calcium isotopic signatures of depleted mid-ocean ridge basalts from the northeastern Pacific. J. Oceanol. Limnol. 38, 1476-1487.

Zhu H., Liao R., Liu H., Du L., Li H., Li C., Zhang Z. and Sun W. (2021) Calcium isotopic fractionation during magma differentiation: Constraints from volcanic glasses from the eastern Manus Basin. Geochim. Cosmochim. Acta 305, 228-242.

Zhu H., Liu F., Li X., An Y., Nan X., Du L., Huang F., Sun W. and Zhang Z. (2020c) Significant $\delta^{44 / 40}$ Ca variations between carbonate- and clay-rich marine sediments from the Lesser Antilles forearc and implications for mantle heterogeneity. Geochim. Cosmochim. Acta 276, 239-257.

Zhu H., Liu F., Li X., Wang G., Zhang Z. and Sun W. (2018) Calcium Isotopic Compositions of Normal MidOcean Ridge Basalts from the Southern Juan de Fuca Ridge. J. Geophys. Res. Solid Earth 123, 13031313.

Zhu P. and Macdougall J. D. (1998) Calcium isotopes in the marine environment and the oceanic calcium cycle. Geochim. Cosmochim. Acta 62, 1691-1698. 


\section{Tables}

2 Table $1 \mathrm{Ca}, \mathrm{Sr}$, and $\mathrm{Nd}$ isotopic compositions of the arc magmas from the Lutao island, Northern Luzon arc

\begin{tabular}{|c|c|c|c|c|c|c|c|c|c|c|}
\hline Sample & $\delta^{44 / 42} \mathrm{Ca}$ & $2 \mathrm{SD}^{\mathrm{a}}$ & $\delta^{43 / 42} \mathrm{Ca}$ & $2 \mathrm{SD}^{\mathrm{a}}$ & $\delta^{44 / 40} \mathrm{Ca}$ & $2 \mathrm{SD}^{\mathrm{a}}$ & $2 \mathrm{SE}^{\mathrm{b}}$ & $n$ & ${ }^{87} \mathrm{Sr} /{ }^{86} \mathrm{Sr}$ & ${ }^{143} \mathrm{Nd} /{ }^{144} \mathrm{Nd}$ \\
\hline LT2-FT1A & 0.42 & 0.05 & 0.20 & 0.05 & 0.87 & 0.10 & 0.06 & 3 & 0.704306 & 0.512714 \\
\hline LT2-FT2 & 0.37 & 0.07 & 0.18 & 0.04 & 0.76 & 0.10 & 0.04 & 6 & 0.705290 & 0.512562 \\
\hline LT2-FT3 & 0.46 & 0.02 & 0.23 & 0.04 & 0.94 & 0.04 & 0.02 & 3 & 0.704830 & 0.512616 \\
\hline LT2-9 & 0.47 & 0.04 & 0.26 & 0.04 & 0.97 & 0.09 & 0.05 & 3 & 0.704167 & 0.512737 \\
\hline LT2-10A & 0.49 & 0.03 & 0.25 & 0.03 & 1.01 & 0.05 & 0.03 & 3 & 0.704707 & 0.512623 \\
\hline LT2-12 & 0.41 & 0.05 & 0.18 & 0.01 & 0.84 & 0.10 & 0.06 & 3 & 0.705168 & 0.512528 \\
\hline LT2-FT14 & 0.48 & 0.01 & 0.25 & 0.01 & 0.98 & 0.03 & 0.02 & 3 & 0.704893 & 0.512563 \\
\hline LT2-FT15 & 0.41 & 0.05 & 0.21 & 0.03 & 0.84 & 0.10 & 0.06 & 3 & 0.704814 & 0.512564 \\
\hline LT2-18A & 0.47 & 0.04 & 0.25 & 0.00 & 0.96 & 0.08 & 0.05 & 3 & 0.704984 & 0.512613 \\
\hline Duplicate & & & & & & & & & 0.704970 & 0.512617 \\
\hline LT2-FT22 & 0.41 & 0.08 & 0.22 & 0.08 & 0.84 & 0.16 & 0.07 & 6 & 0.704858 & 0.512603 \\
\hline Duplicate & 0.39 & 0.04 & 0.20 & 0.02 & 0.80 & 0.08 & 0.03 & 6 & & \\
\hline \multicolumn{11}{|l|}{ Standards } \\
\hline NBS987 & & & & & & & & & 0.710241 & \\
\hline JNdi-1 & & & & & & & & & & 0.512118 \\
\hline BCR-2 & 0.36 & 0.02 & 0.17 & 0.04 & 0.73 & 0.04 & 0.03 & 3 & 0.705009 & 0.512641 \\
\hline AGV-2 & & & & & & & & & 0.703984 & 0.512787 \\
\hline Seawater & 0.94 & 0.04 & 0.47 & 0.07 & 1.93 & 0.09 & 0.05 & 3 & & \\
\hline BHVO-2 & 0.37 & 0.00 & 0.17 & 0.04 & 0.76 & 0.01 & 0.00 & 3 & & \\
\hline SRM915b & 0.40 & 0.04 & 0.18 & 0.09 & 0.82 & 0.08 & 0.05 & 3 & & \\
\hline
\end{tabular}

3

4 a 2SD: two standard deviations.

5 b 2SE: two standard deviations of the mean. $2 \mathrm{SE}=2 \mathrm{SD} / \sqrt{n}, n$ is number of replicate analyses of Ca isotopic 6 compositions.

7 


\section{$8 \quad$ Figures}

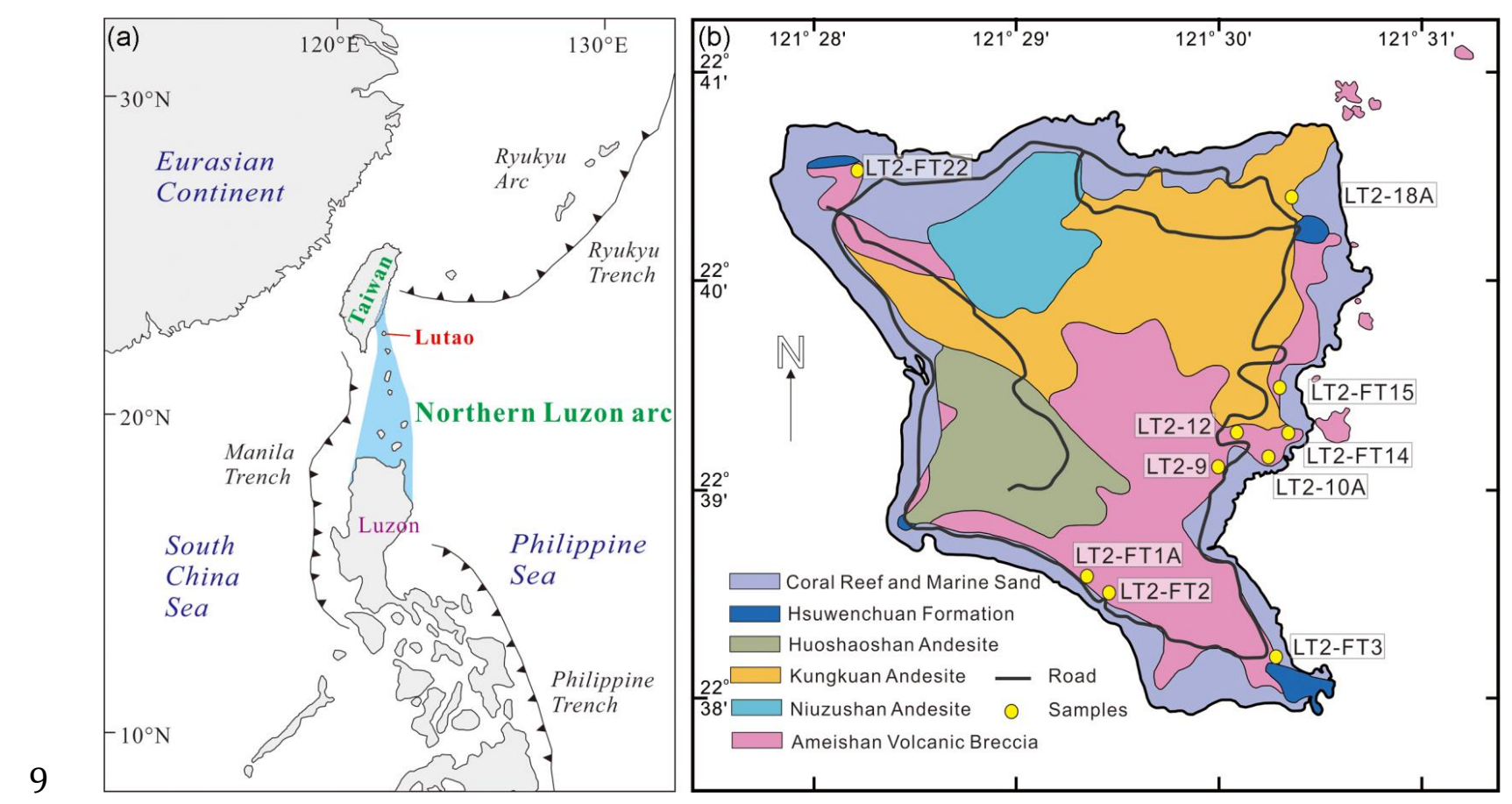

10 Fig. 1 (a) Geological setting of the Northern Luzon arc (modified from Ho, 1986) and (b) the location of samples

11 from the Lutao island. 


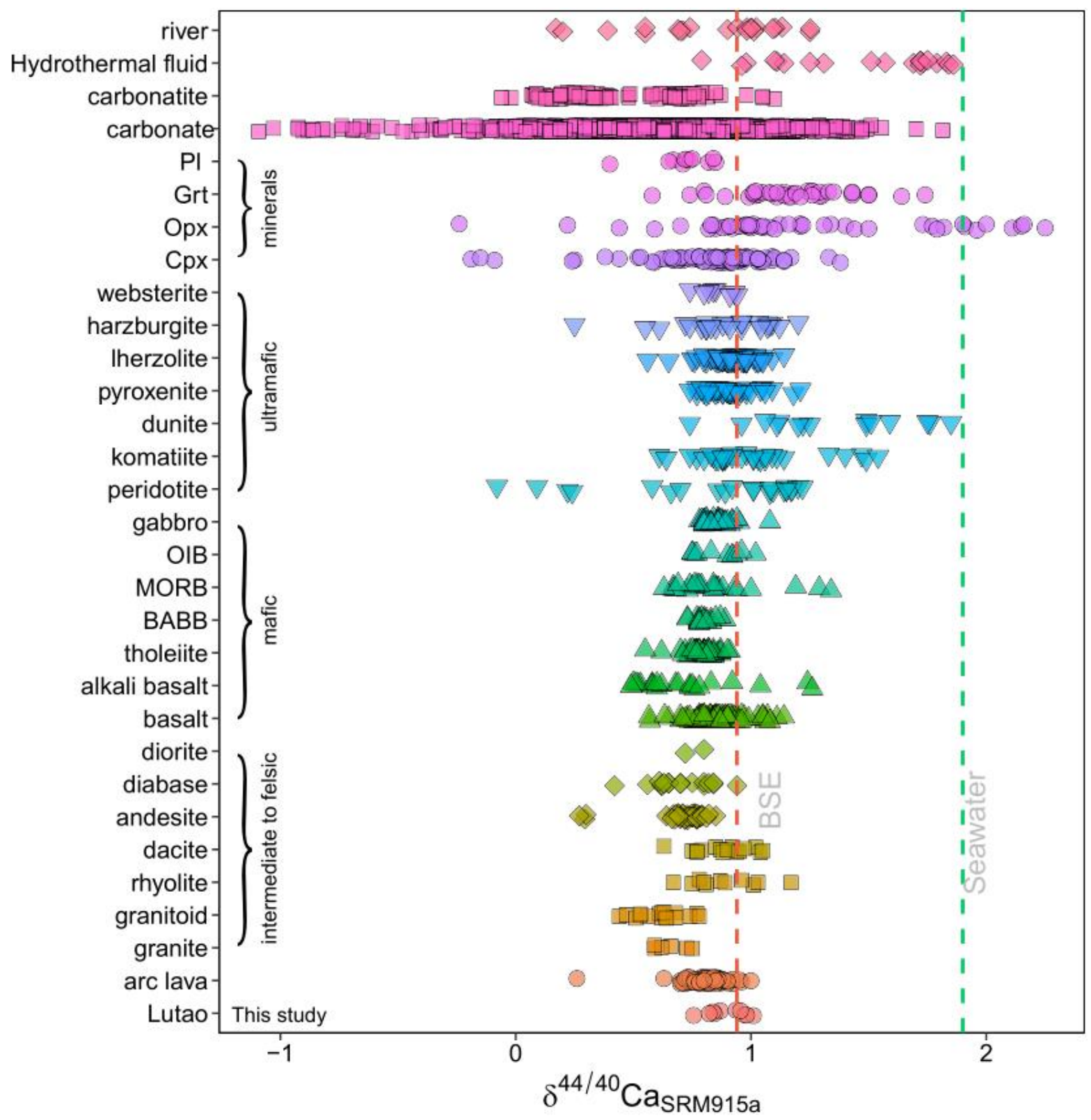

13 Fig. $2 \delta^{44 / 40} \mathrm{Ca}$ values of the arc magmas from the Lutao island, Northern Luzon arc. The $\delta^{44 / 40} \mathrm{Ca}$ variations in river

14 (Zhu and Macdougall, 1998; Jacobson et al., 2015); seawater, hydrothermal fluids, and carbonate (Fantle and

15 Tipper, 2014 and references therein); carbonatite (He et al., 2017; Banerjee and Chakrabarti, 2019; Amsellem et 16 al., 2020; Sun et al., 2021); representative minerals (Pl - plagioclase, Grt - garnet, Opx - orthopyroxene, Cpx 17 clinopyroxene) (Skulan et al., 1997; Huang et al., 2010; Kang et al., 2016, 2019, 2020; Zhao et al., 2017; Chen et 18 al., 2018, 2019, 2020a, b; Wang et al., 2019; Dai et al., 2020; Gussone et al., 2020); Igneous rocks: ultramafic 19 rocks (websterite, harzburgite, lherzolite, dunite, komatiite, peridotite), mafic rocks (gabbro, OIB - ocean island 20 basalt, MORB - mid-ocean ridge basalts, BABB - back-arc basin basalts, tholeiite, alkali basalt), intermediate 21 felsic rocks (diorite, diabase, andesite, dacite, rhyolite, granitoid, and granite) (Skulan et al., 1997; DePaolo, 2004; 
22 Amini et al., 2009; Simon and DePaolo, 2010; Huang et al., 2010, 2011; John et al., 2012; Valdes et al., 2014;

23 Kang et al., 2016, 2017, 2019, 2020; Feng et al., 2017; Liu et al., 2017; He et al., 2017; Amsellem et al., 2017,

24 2019; Zhao et al., 2017; Zhang et al., 2018; Zhu et al., 2018, 2020a, b, 2021; Banerjee and Chakrabarti, 2018, 2019; Chen et al., 2018, 2019, 2020a; Wang et al., 2019; Ionov et al., 2019; Dai et al., 2020), and previously reported arc magmas from Tonga, Mariana, Central America, Southern Lesser Antilles, and Central-eastern Aleutian arcs (Wang et al., 2021; Kang et al., 2021) are also shown for comparison. The proposed $\delta^{44 / 40}$ Ca value of BSE (0.94 $\pm 0.05 \%$, Kang et al., 2017) is shown as a dashed orange line.
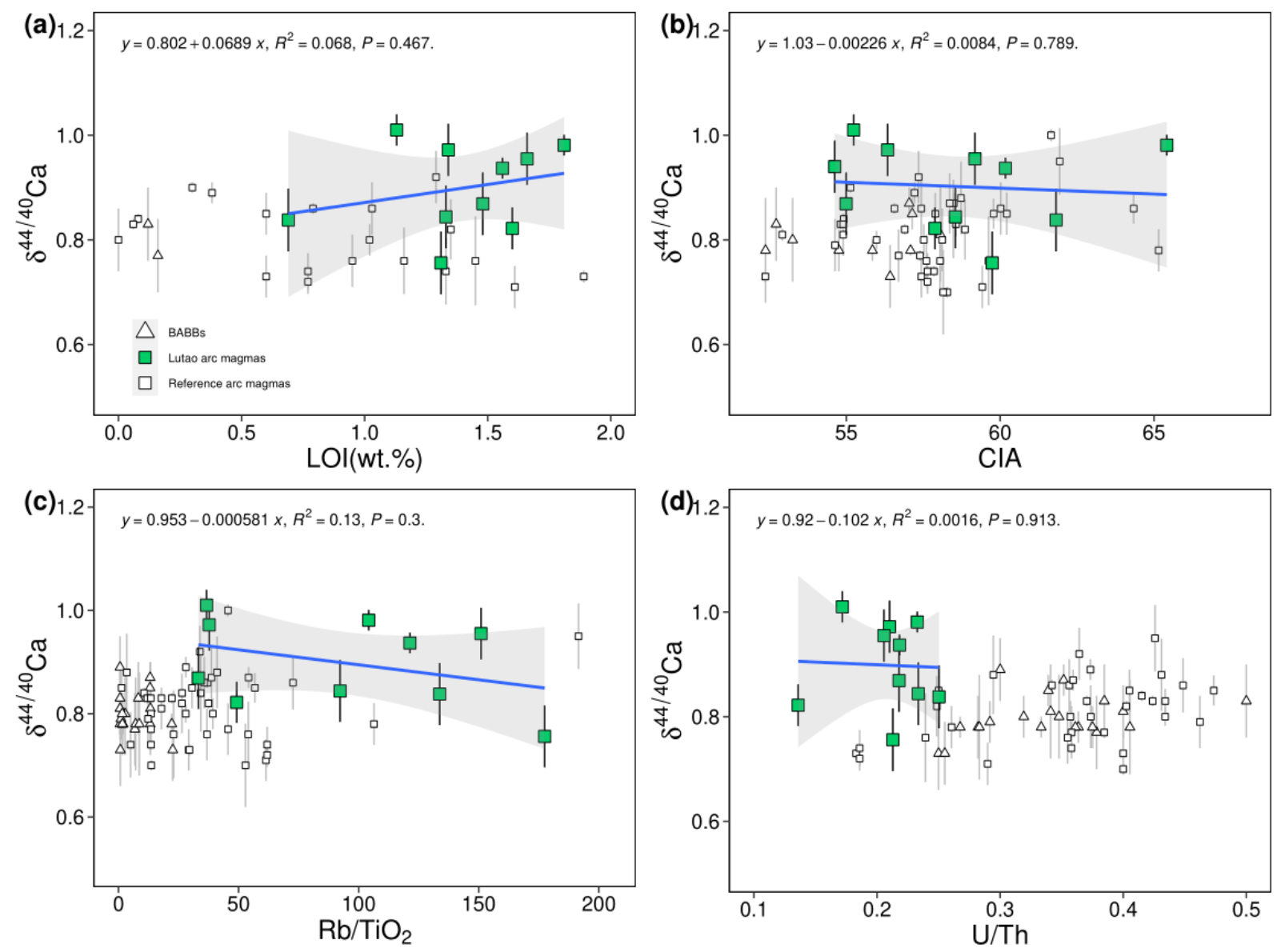

Fig. 3 Correlations between $\delta^{44 / 40} \mathrm{Ca}$ and (a) LOI,

(b) $\mathrm{CIA}\left(=\mathrm{Al}_{2} \mathrm{O}_{3} /\left(\mathrm{Na}_{2} \mathrm{O}+\mathrm{K}_{2} \mathrm{O}+\mathrm{Al}_{2} \mathrm{O}_{3}+\mathrm{CaO}\right) \times 100\right)$, (c)

$31 \log \left(\mathrm{Rb} / \mathrm{TiO}_{2}\right)$, and (d) $\log (\mathrm{U} / \mathrm{Th})$ values of the Lutao arc magmas. The data for previously reported BABBs and 32 arc magmas (Zhu et al., 2020a; Wang et al., 2021; Kang et al., 2021) are also shown for comparison. 

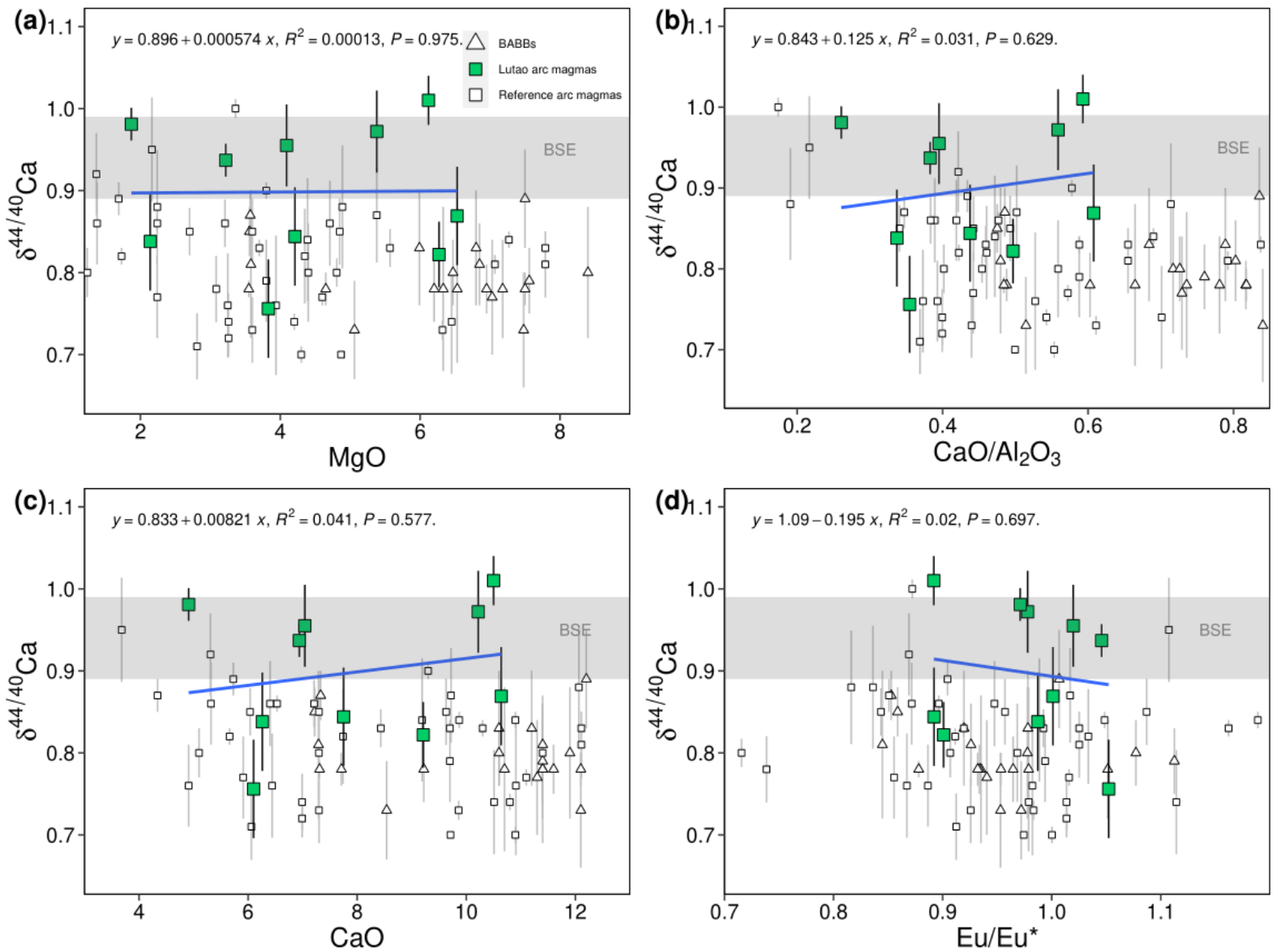

34 Fig. 4 Variations of $\delta^{44 / 40} \mathrm{Ca}$ values of the Lutao volcanics as a function of (a) $\mathrm{MgO}$, (b) $\mathrm{CaO} / \mathrm{Al}_{2} \mathrm{O}_{3}$, (c) $\mathrm{CaO}$, and

(d) $\mathrm{Eu} / \mathrm{Eu}^{*} \cdot \mathrm{Eu} / \mathrm{Eu}^{*}=\mathrm{Eu}_{\mathrm{N}} / \sqrt{\mathrm{Sm}_{\mathrm{N}} \times \mathrm{Gd}_{\mathrm{N}}}$ where the subscript $N$ indicates normalization by CI chondrite

(McDonough and Sun, 1995). Previously reported data for BABBs and arc magmas (Zhu et al., 2020a; Wang et

BSE (Kang et al., 2017). 


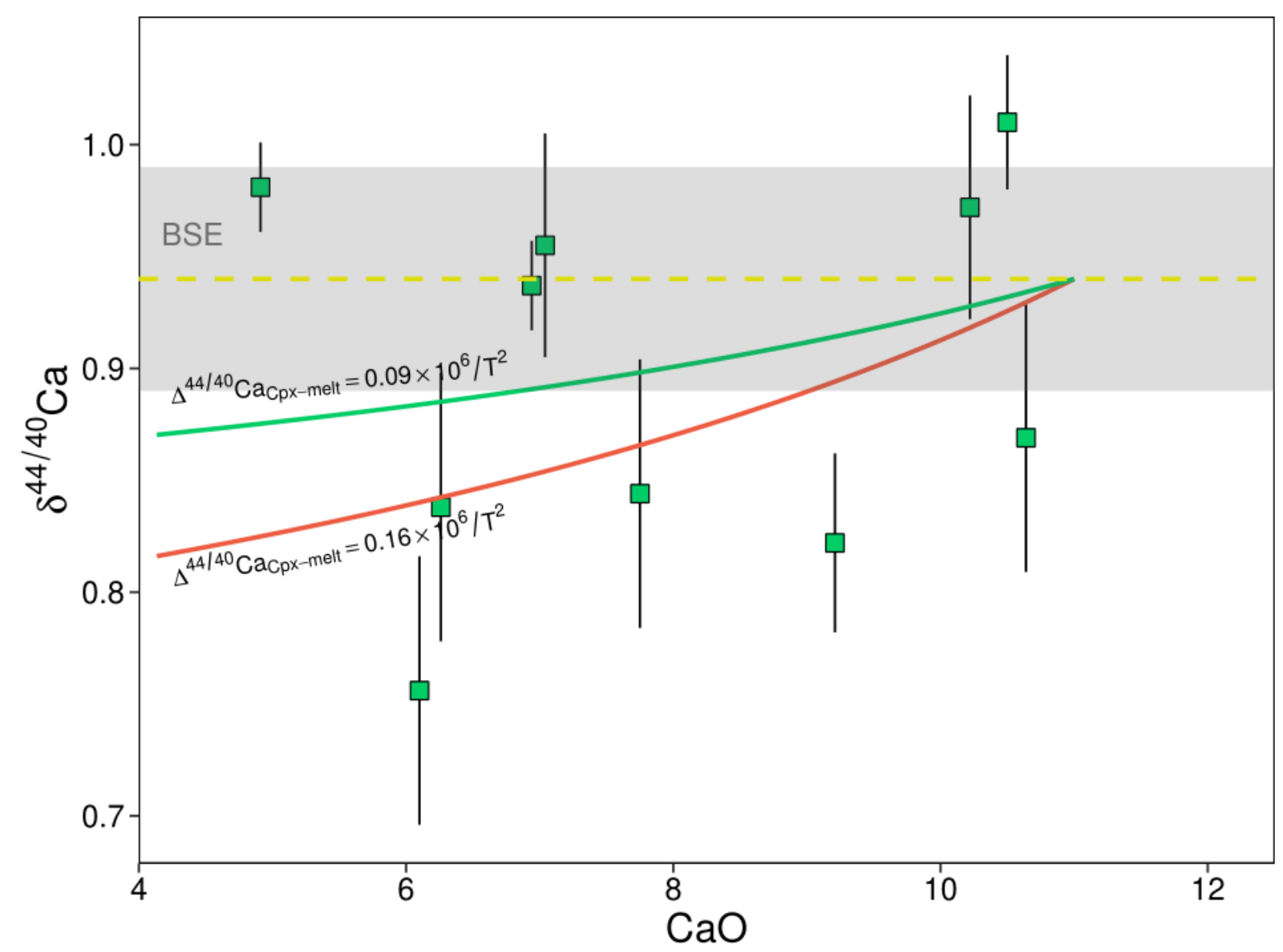

40 Fig. 5: Variation of $\delta^{44 / 40} \mathrm{Ca}$ with $\mathrm{CaO}$ contents of the arc magmas from Lutao, Northern Luzon arc, by assuming

41 the $\mathrm{CaO}$ decreasing was solely attributed to the $\mathrm{Cpx}$ accumulation during magma cooling. The $\delta^{44 / 40} \mathrm{Ca}$ and $\mathrm{CaO}$

42 contents of the primary magma are set as $0.94 \%$ and $11 \mathrm{wt} . \%$, respectively. The $\mathrm{CaO}$ content of Cpx is $21.3 \mathrm{wt} . \%$

43 (Table S2). The Ca isotope fractionations between Cpx and melt $\left(\Delta^{44 / 40} \mathrm{Ca}_{\mathrm{Cpx}-\mathrm{melt}}\right)$ are $0.09 \times 10^{6} / \mathrm{T}^{2}(\mathrm{green}$ line)

44 and $0.16 \times 10^{6} / \mathrm{T}^{2}$ (red line), respectively (Zhang et al., 2018). The temperature is set as $\mathrm{T}=1000 \mathrm{~K}(\mathrm{Chen}, 1986)$. 

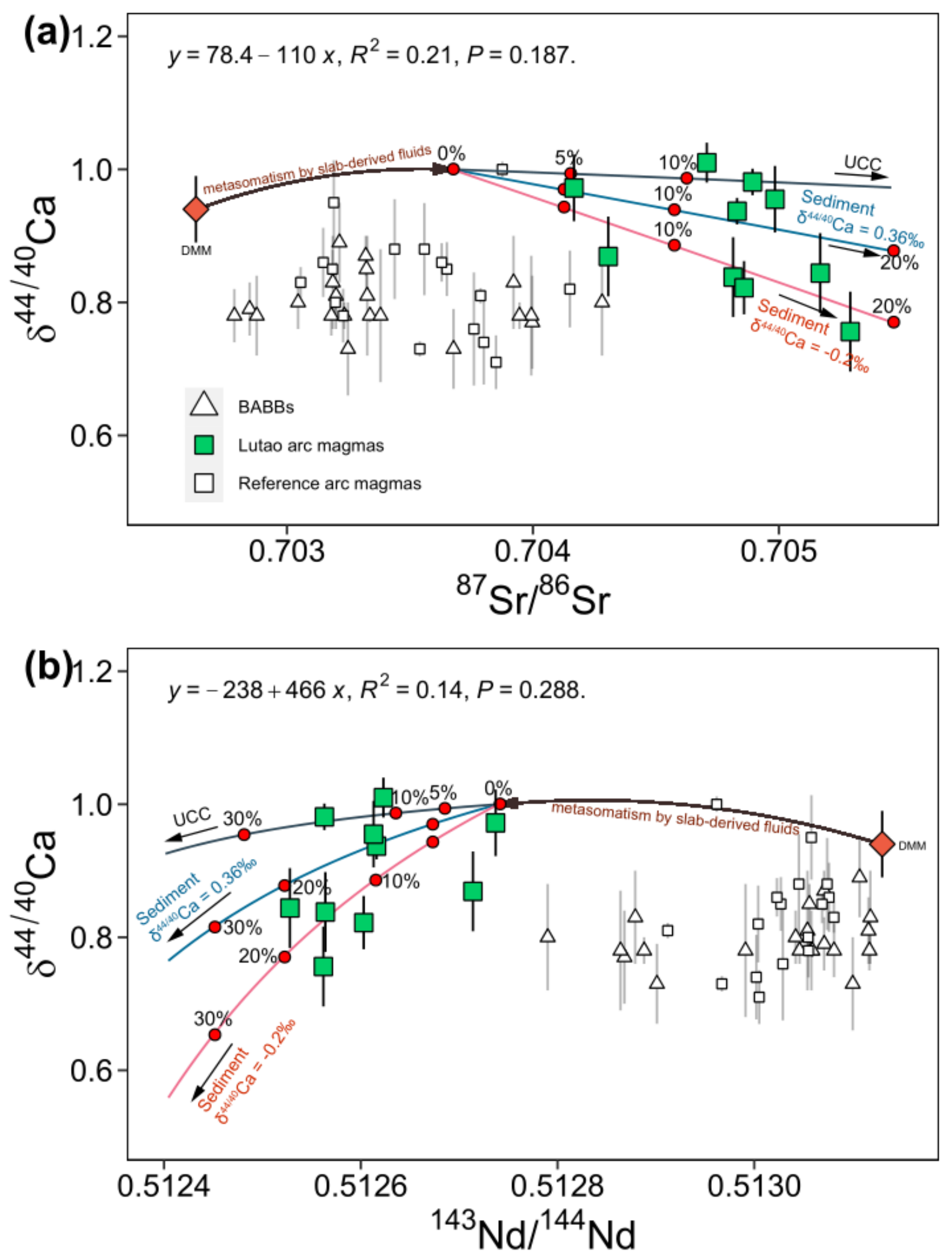

46 Fig. 6 Correlations between $\delta^{44 / 40} \mathrm{Ca}$ and $\mathrm{Sr}-\mathrm{Nd}$ isotopic compositions of the Lutao arc magmas. The lines with

47 numbers demonstrate the simple mixing between the arc magma metasomatized by subduction fluids (AMMF)

48 and SCS sediment or UCC, respectively. The numbers along the mixing lines show the modeled percentage 
50 for comparison (Zhu et al., 2020a; Wang et al., 2021; Kang et al., 2021). The endmember values are shown in 51 supporting Information Table S4.
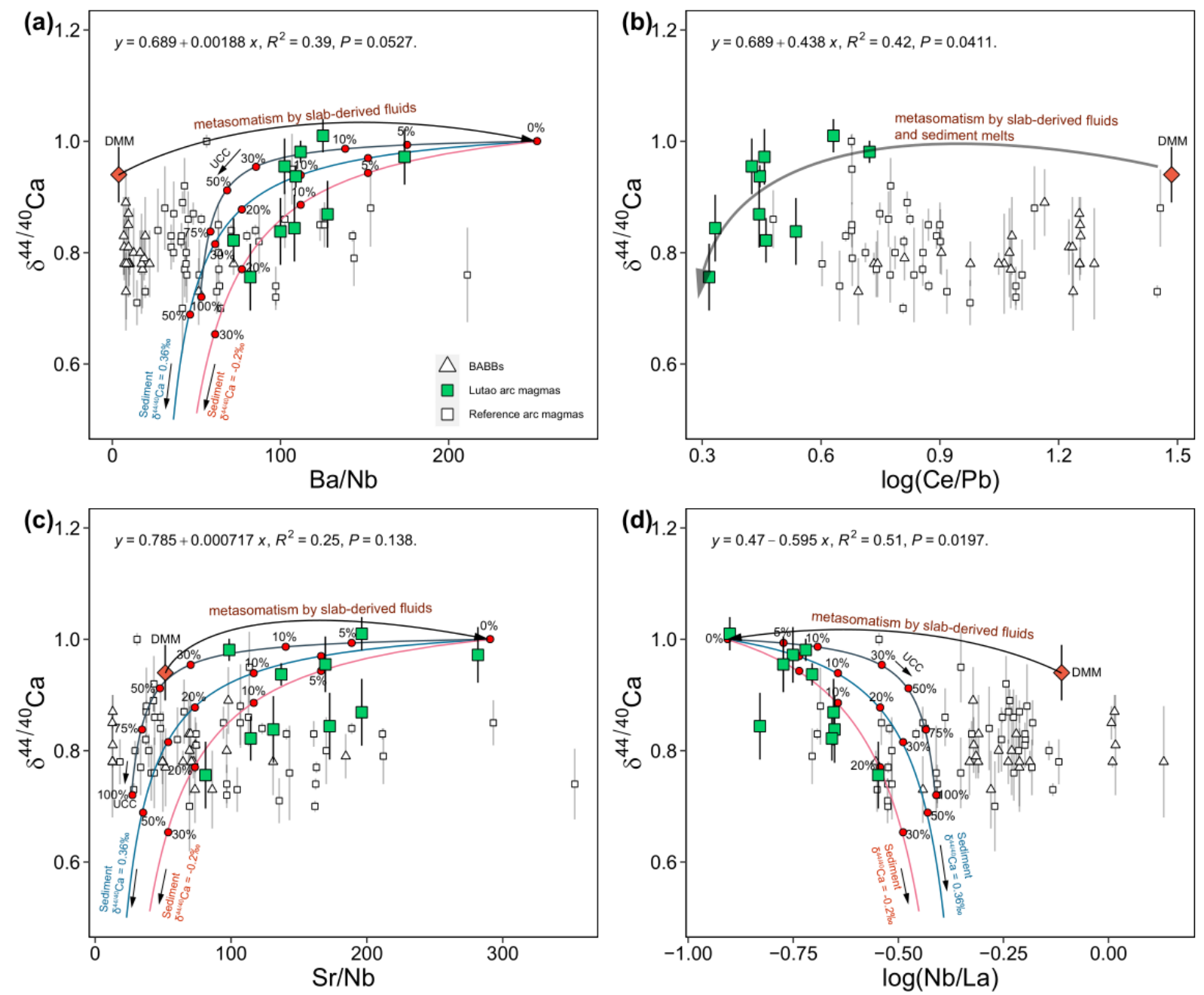

53 Fig. 7: Variations of Lutao $\delta^{44 / 40} \mathrm{Ca}$ values with subduction indicators: (a) $\mathrm{Ba} / \mathrm{Nb},(\mathrm{b}) \log (\mathrm{Ce} / \mathrm{Pb}),(\mathrm{c}) \mathrm{Sr} / \mathrm{Nb}$, and

54 (d) $\log (\mathrm{Nb} / \mathrm{La})$. The lines with numbers demonstrate the simple mixing between AMMF and SCS sediment or

55 UCC. The numbers along the mixing lines show the estimated percentage contributions of the sediment melts or

56 UCC. The data previously reported for BABBs and arc magmas are also shown for comparison (Zhu et al., 2020a;

57 Wang et al., 2021; Kang et al., 2021). The endmember values are shown in Table S4. 
58

59 Fig. 8 Temperature-pressure conditions of slabs underneath the global trenches (Syracuse et al., 2010). The global

60 range of slab surface temperatures are derived from Syracuse et al. (2010) using D80 model. The solidus of $\mathrm{H}_{2} \mathrm{O}-$

61 saturated sediment melting at $2.5-3.2 \mathrm{GPa}$ and $670-950{ }^{\circ} \mathrm{C}$ is adopted from Keken et al. (2011). Subduction

62 rate, sediment density, bulk $\mathrm{CaO}, \mathrm{H}_{2} \mathrm{O}, \mathrm{CO}_{2}$ contents of subducted sediments are proposed by Plank (2014). The

63 thicknesses of subducted sediments are compiled by Scholl and von Huene (2007) and Syracuse et al. (2010)

64 considering the accreting of sediment during subduction. The fluxes of sedimentary Ca are calculated from these

65

66

67

parameters by assuming all sedimentary inorganic carbon and $\mathrm{Ca}$ are stored as $\mathrm{CaCO}_{3}$. The ratio of organic carbon is set as $20 \%$ on a global scale (Plank and Manning, 2019). The detailed dataset of subduction parameters, subducting sediments, and estimated sedimentary Ca fluxes are shown in Table S5.

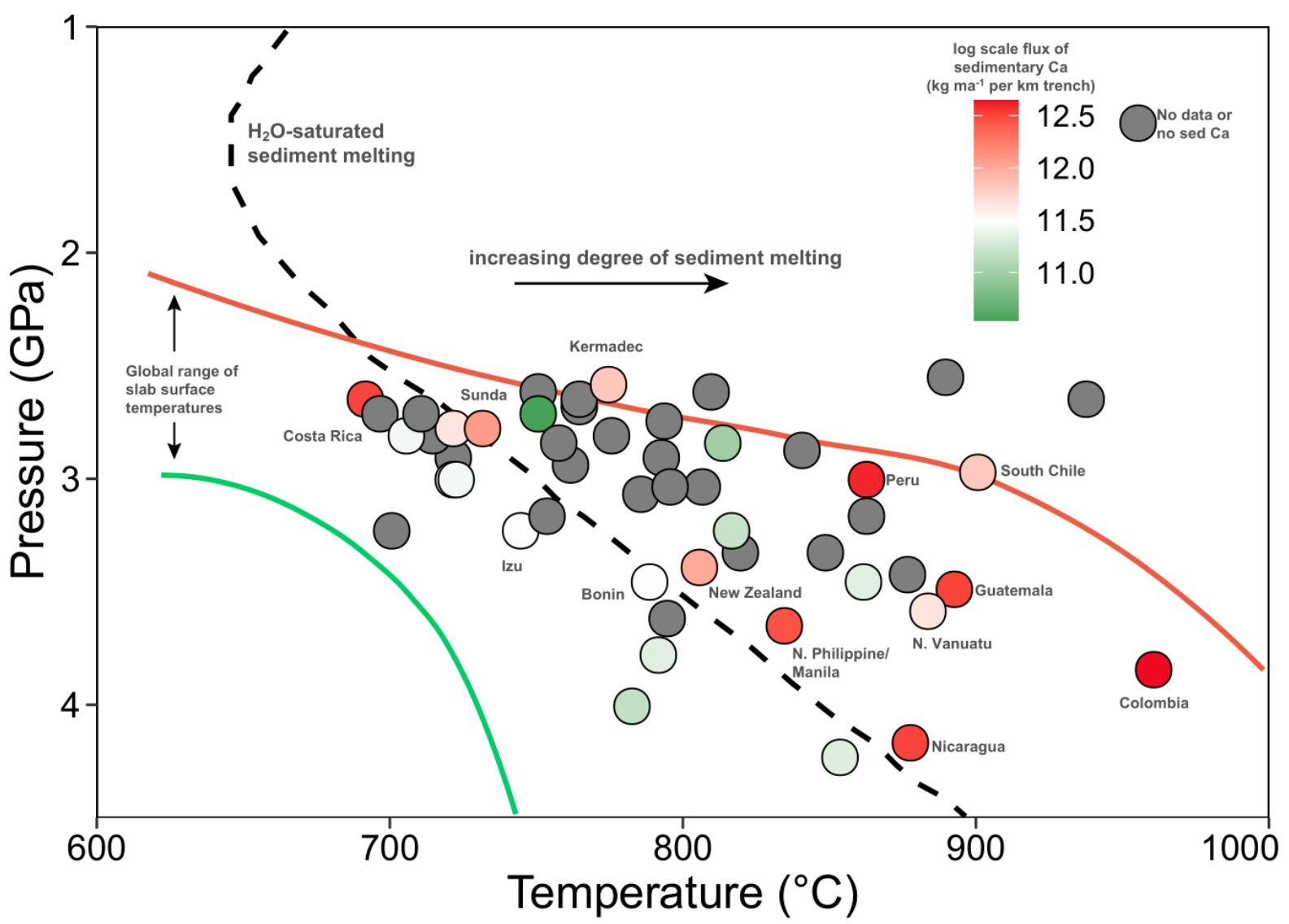




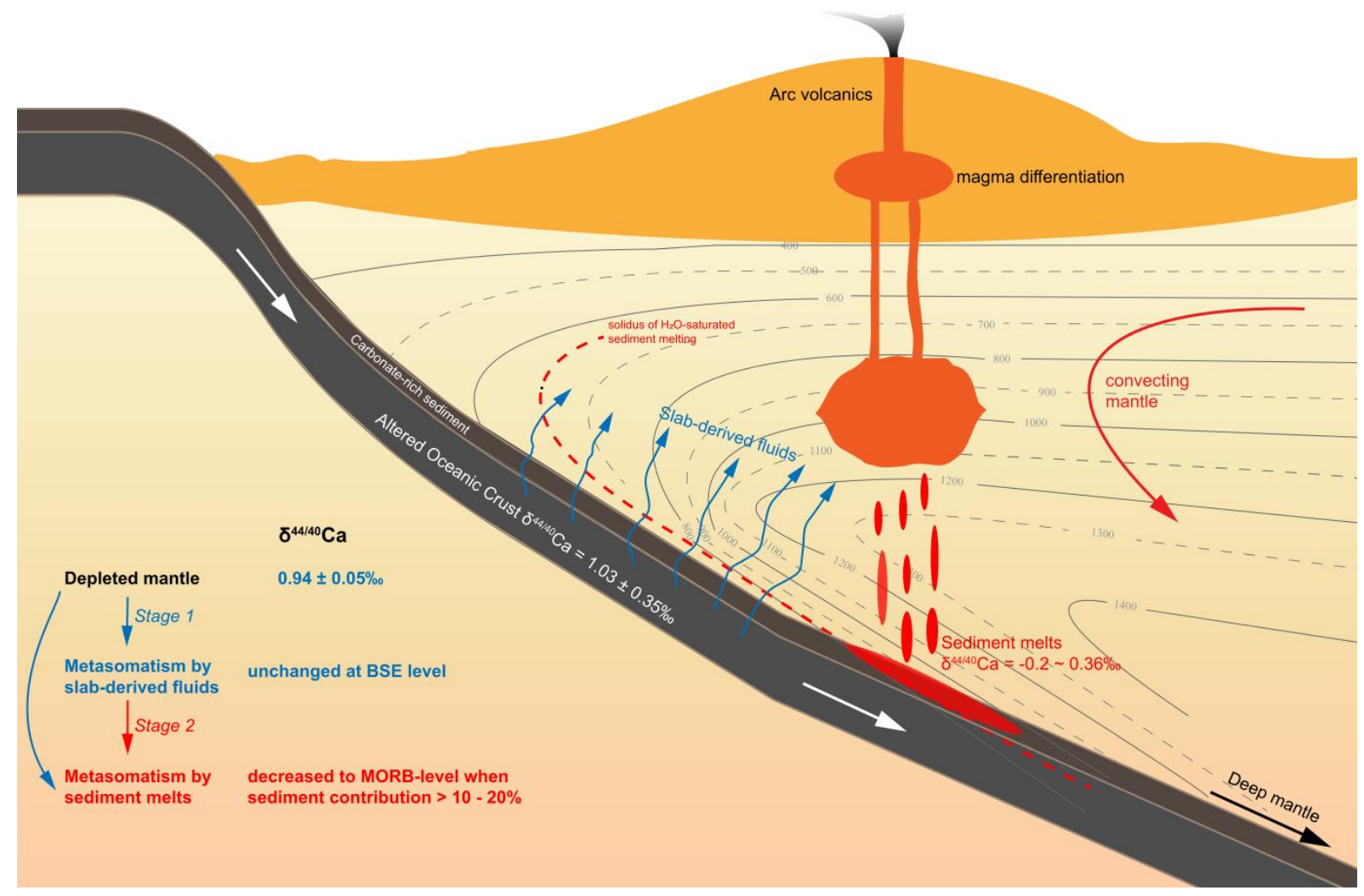

69 Fig. 9 Sketch demonstrating the influence of magmatic processes and subduction-related metasomatism on the Ca

70 isotopic characteristics of arc magmas.

71 


\title{
Supporting Information:
}

Recycling of marine carbonate induced Calcium isotope heterogeneity of

\author{
arc magmas in subduction zones \\ Xue-Gang Chen ${ }^{\mathrm{a},}$ *, Tao $\mathrm{Wu}^{\mathrm{a}}$, Qin Gao ${ }^{\mathrm{a}}$, Yu-Ming $\mathrm{Lai}^{\mathrm{b}}$ \\ ${ }^{a}$ Ocean College, Zhejiang University, Zhoushan 316021, P.R. China \\ ${ }^{\mathrm{b}}$ Department of Earth Sciences, National Taiwan Normal University, Taipei 11677, Taiwan \\ Corresponding author: Xue-Gang Chen, email: chenxg83@zju.edu.cn, Tel: +86-580-2092326, Fax: +86- \\ 580-2092891.
}

This file includes:

Fig. S1

Fig. S2

Fig. S3

Fig. S4

Fig. S5

Fig. S6

Table S1 (in attached excel file)

Table S2

Table S3

Table S4

Table S5 (in attached excel file) 


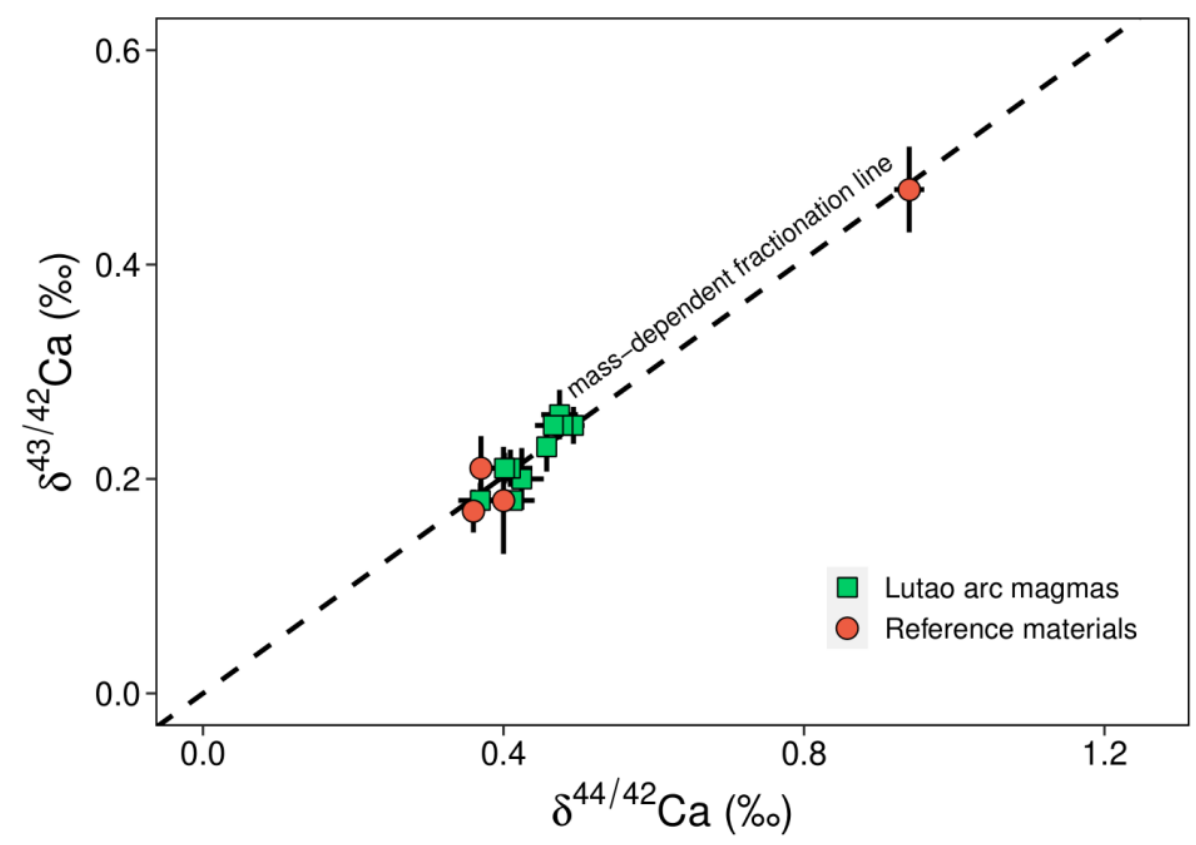

Fig. S1 Correlation between measured $\delta^{43 / 42} \mathrm{Ca}$ and $\delta^{44 / 42} \mathrm{Ca}$ of all Lutao arc magmas and reference materials. All the values plot on the theoretical mass-dependent fractionation line with a slope of 0.506 (Heuser, 2016).

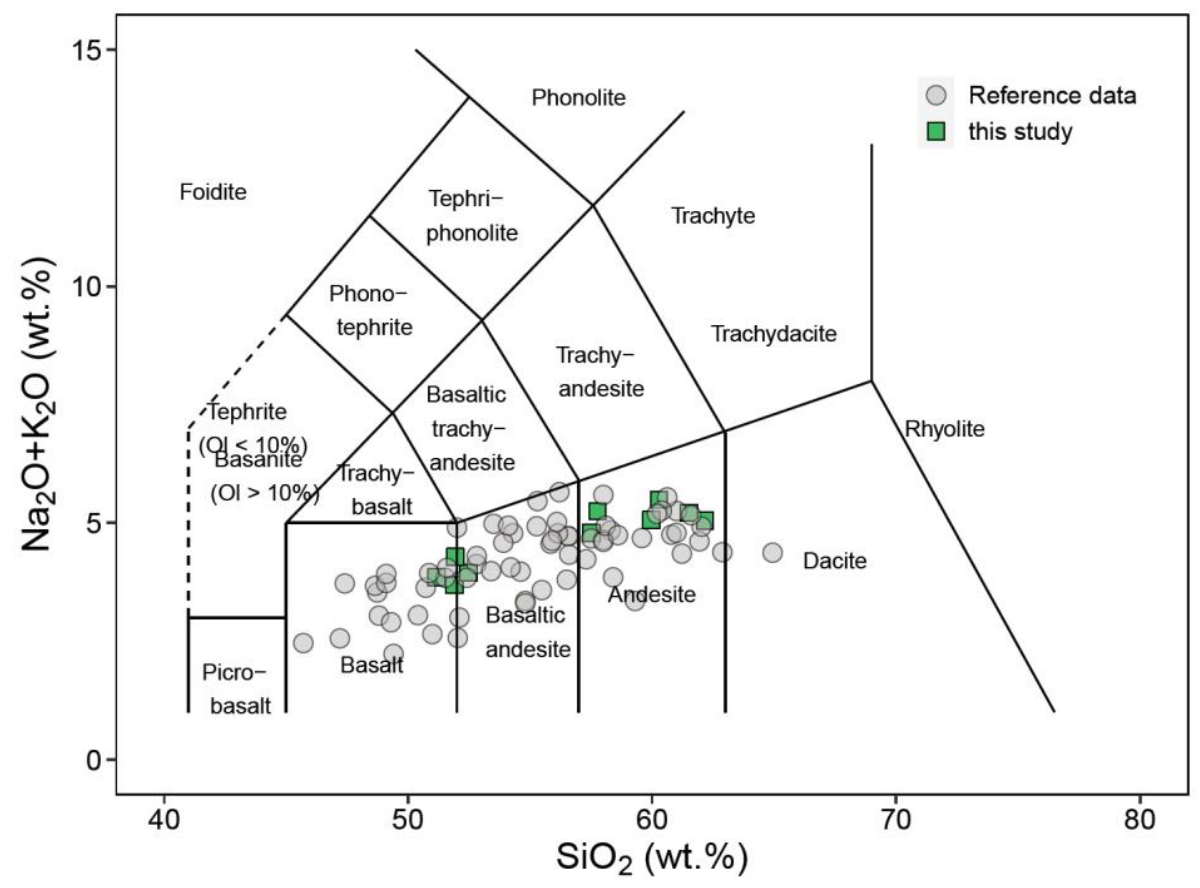

Fig. S2 TAS diagram of Lutao volcanic rocks. The gray points indicate the data for the Lutao volcanics previously published by Yang (1992), Chen and Lin (1980), McDermott et al. (1993), and Marini et al. (2005). 

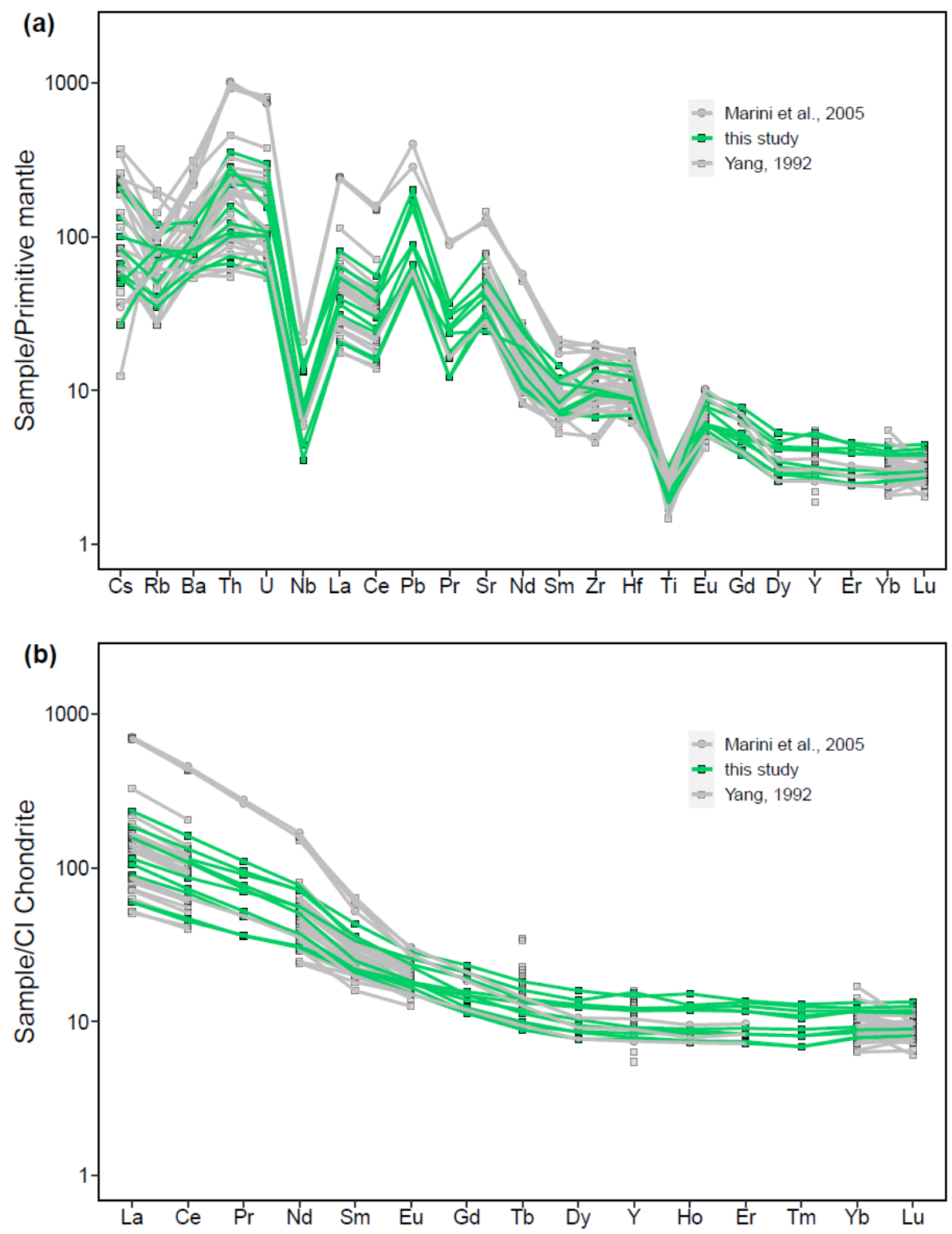

Fig. S3 (a) Primitive mantle normalized trace element distribution patterns and (b) CI Chondrite normalized REE patterns of Lutao volcanic rocks. The chemical compositions of primitive mantle and chondrite are adopted from Sun and McDonough (1989) and McDonough and Sun (1995). Previously published data on Lutao volcanics (Yang, 1992; Marini et al., 2005) are also shown for comparison. 

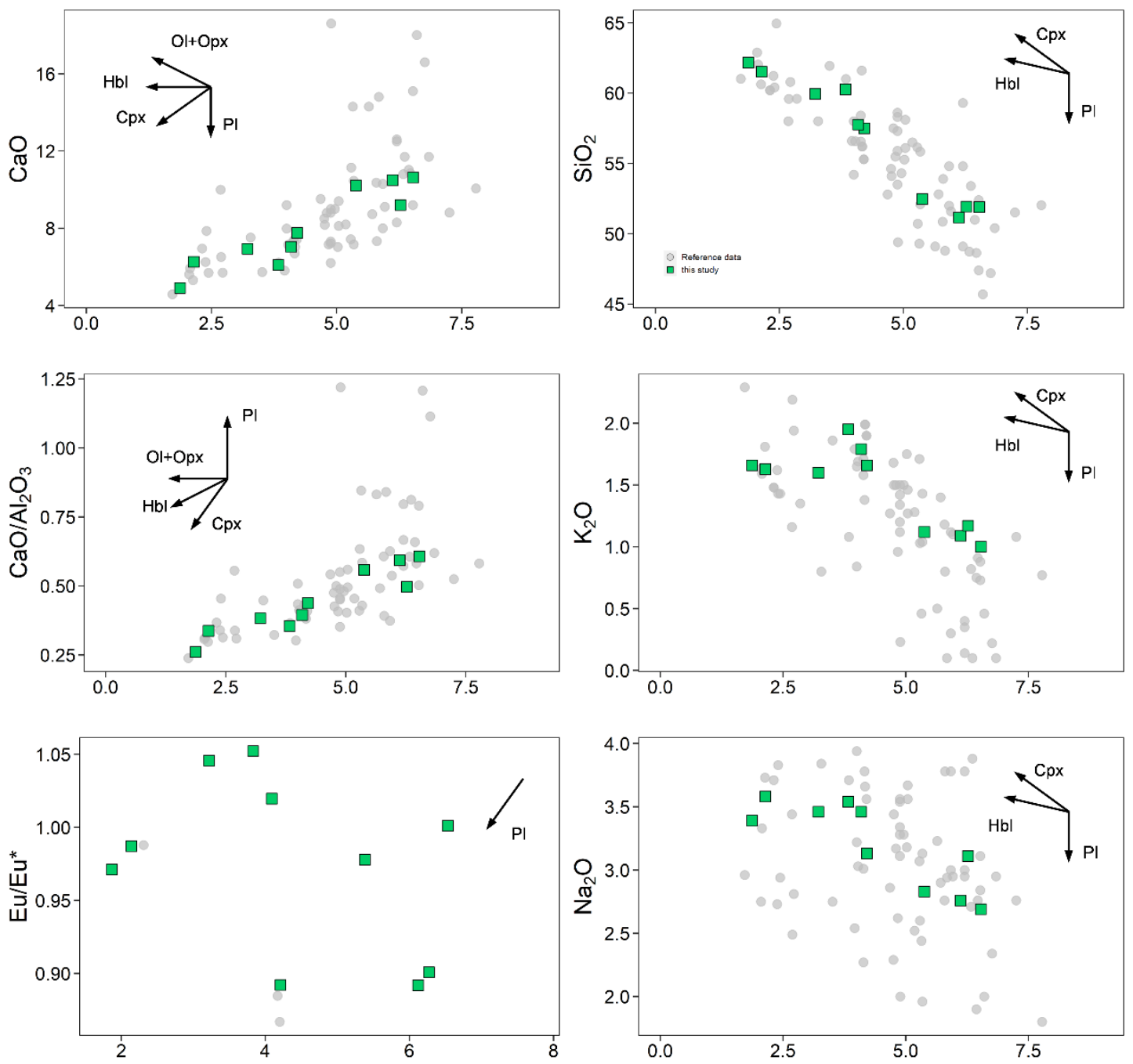

$\mathrm{MgO}$ (wt.\%)

Figure S4: Correlations between $\mathrm{MgO}$ and $\mathrm{CaO}, \mathrm{SiO}_{2}, \mathrm{CaO} / \mathrm{Al}_{2} \mathrm{O}_{3}, \mathrm{~K}_{2} \mathrm{O}, \mathrm{Na}_{2} \mathrm{O}$, and $\mathrm{Eu} / \mathrm{Eu}^{*}, \mathrm{TiO}_{2}$, and $\mathrm{SiO}_{2}$ to show the fractional crystallization of $\mathrm{Hbl}, \mathrm{Cpx}, \mathrm{Pl}$, and $\mathrm{Ol}$. The data for Lutao volcanics (gray points) reported by previous works are also shown for comparison (Chen and Lin, 1980; Yang, 1992; McDermott et al., 1993; Marini et al., 2005). 


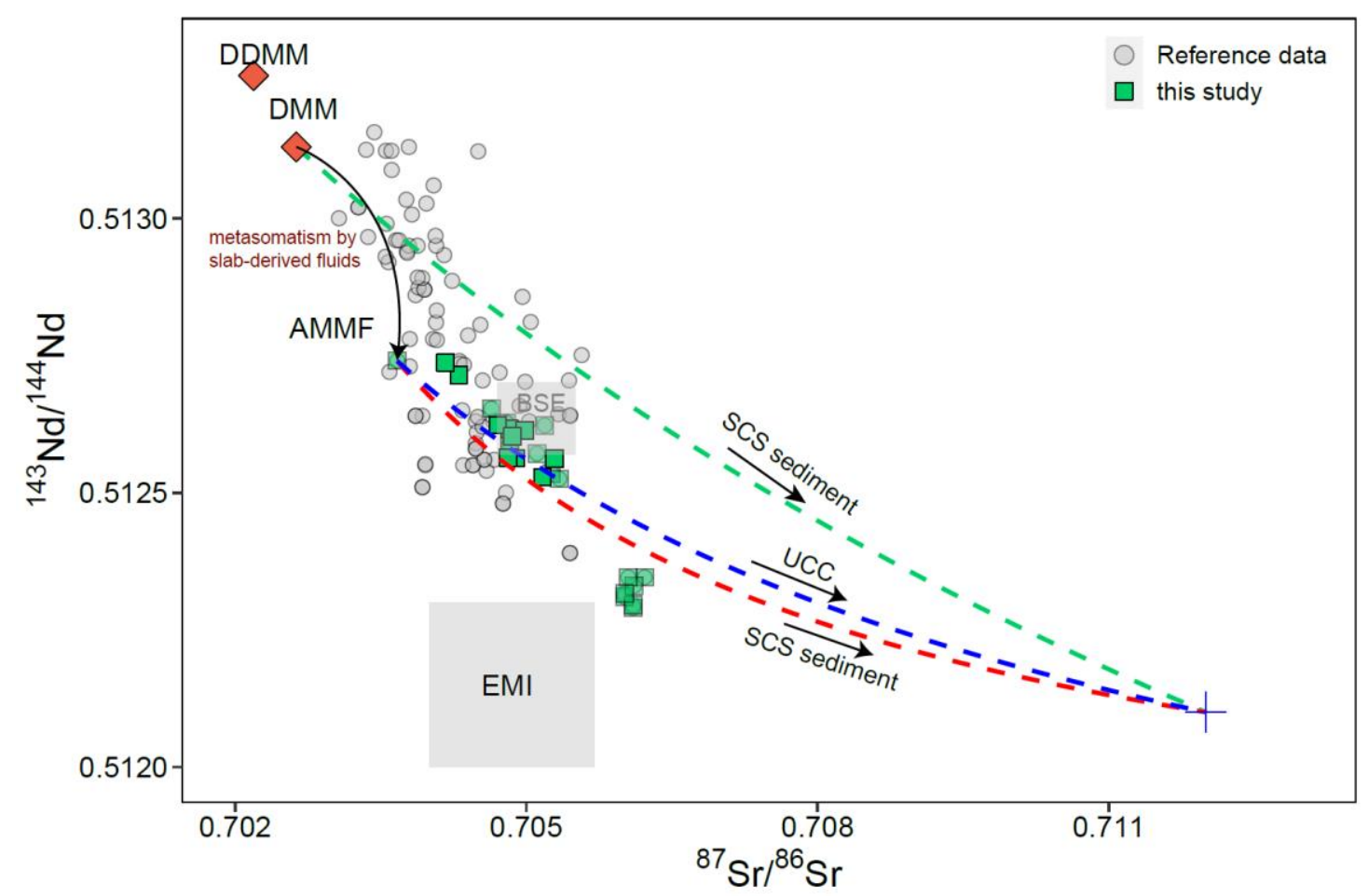

Fig. S5: Sr-Nd isotopic compositions of Lutao arc magmas. Previously reported data for the northern Luzon arc volcanics are also shown for comparison (Defant et al., 1990; Chen et al., 1990; McDermott et al., 1993; Marini et al., 2005). The values for EMI, BSE, DMM, and DDMM are proposed by Zindler and Hart (1986) and Workman and Hart (2005). The green line indicates the mixing between DMM and SCS sediment. The orange line demonstrates the mixing between the melting of DMM metasomatized by slab-derived fluids (denotes as AMMF) and subducting sediment of South China Sea (SCS). The blue line represents the mixing between AMMF and upper continental crust (UCC). The endmember values are shown in Table S4. 


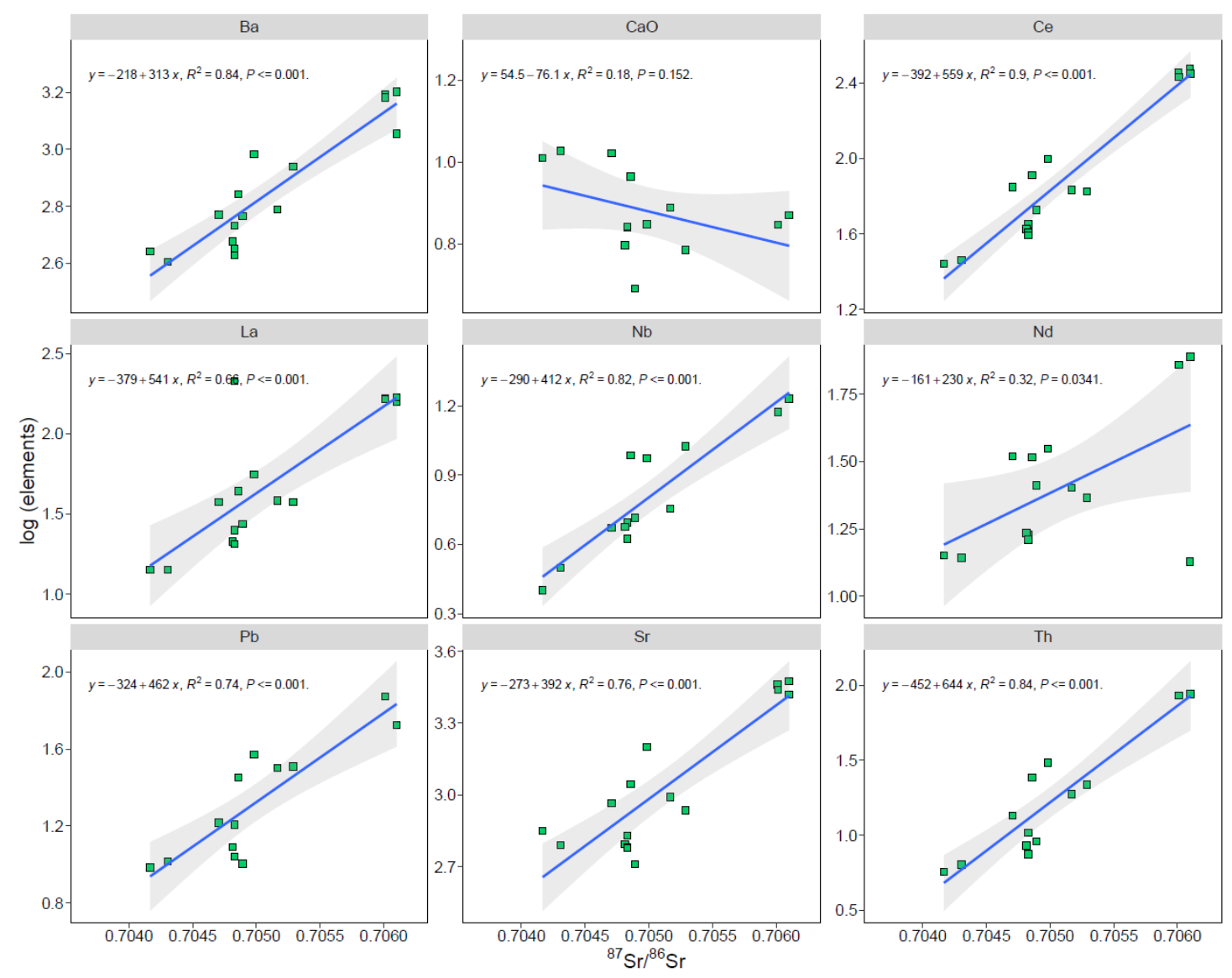

Fig. S6 Correlations between $\log$ (elements) and ${ }^{87} \mathrm{Sr} /{ }^{86} \mathrm{Sr}$ of the Lutao volcanics to estimate the chemical compositions of the Lutao arc magma metasomatized by subduction fluids (AMMF). The estimations for $\mathrm{Nb}, \mathrm{Nd}$, and $\mathrm{CaO}$ may have been significantly biased on accounts of their low correlation coefficients or low endmember values. 
Table S1 Chemical compositions of the arc lavas from Lutao island, Northern Luzon arc.

See the attached excel file

Table S2 Chemical compositions of the phenocrysts in the Lutao arc magmas determined by in-situ EPMA. $n$ indicates the number of analyzed crystals.

\begin{tabular}{|c|c|c|c|c|c|c|c|c|c|c|c|c|c|c|c|}
\hline sample & mineral & $\mathrm{SiO}_{2}$ & $\mathrm{Na}_{2} \mathrm{O}$ & $\mathbf{K}_{2} \mathbf{O}$ & MnO & $\mathbf{A l}_{2} \mathbf{O}_{3}$ & MgO & $\mathrm{CaO}$ & $\mathrm{FeO}$ & $\mathbf{P}_{2} \mathbf{O}_{5}$ & $\mathrm{NiO}$ & $\mathrm{TiO}_{2}$ & $\mathrm{Cr}_{2} \mathrm{O}_{3}$ & Total & $n$ \\
\hline LT2-10A & \multirow{6}{*}{ Cpx } & 51.6 & 0.22 & 0.01 & 0.18 & 3.65 & 15.5 & 21.5 & 6.51 & 0.03 & 0.04 & 0.42 & 0.15 & 99.7 & 13 \\
\hline LT2-12 & & 52.9 & 0.21 & 0.01 & 0.20 & 2.50 & 17.0 & 20.3 & 6.19 & 0.05 & 0.04 & 0.34 & 0.30 & 99.9 & 16 \\
\hline LT2-9 & & 51.7 & 0.32 & 0.01 & 0.23 & 3.14 & 15.7 & 20.7 & 7.52 & 0.02 & 0.06 & 0.59 & 0.06 & 100.1 & 21 \\
\hline LT2-FT22 & & 51.7 & 0.26 & 0.01 & 0.16 & 4.01 & 15.9 & 22.1 & 5.52 & 0.02 & 0.04 & 0.46 & 0.35 & 100.5 & 32 \\
\hline LT2-FT1A & & 51.6 & 0.28 & 0.01 & 0.18 & 3.65 & 15.8 & 21.4 & 6.44 & 0.02 & 0.04 & 0.51 & 0.18 & 100.1 & 31 \\
\hline Average & & $51.8 \pm 1.3$ & $0.26 \pm 0.08$ & I & $0.19 \pm 0.09$ & $3.50 \pm 1.29$ & $15.9 \pm 1.3$ & $21.3 \pm 2.1$ & $6.36 \pm 1.73$ & I & I & 0.48 & 0.23 & & \\
\hline LT2-10A & \multirow{10}{*}{$\mathrm{Hbl}$} & 42.8 & 2.22 & 0.7 & 0.11 & 13.4 & 15.5 & 11.7 & 9.38 & 0.02 & 0.04 & 1.53 & 0.04 & 97.4 & 8 \\
\hline LT2-12 & & 44.1 & 2.01 & 0.53 & 0.14 & 12.5 & 15.6 & 11.4 & 9.74 & 0.02 & 0.05 & 1.34 & 0.10 & 97.5 & 12 \\
\hline LT2-18A & & 44.5 & 2.15 & 0.6 & 0.13 & 12.6 & 16.6 & 11.6 & 8.44 & 0.03 & 0.06 & 1.12 & 0.09 & 97.8 & 16 \\
\hline LT2-9 & & 42.7 & 2.46 & 0.61 & 0.11 & 13.5 & 15.6 & 11.6 & 9.62 & 0.02 & 0.02 & 1.96 & 0.12 & 98.4 & 2 \\
\hline LT2-FT22 & & 44.0 & 2.23 & 0.62 & 0.09 & 12.7 & 15.9 & 11.8 & 9.36 & 0.02 & 0.04 & 1.63 & 0.04 & 98.4 & 1 \\
\hline LT2-FT14 & & 45.3 & 1.68 & 0.28 & 0.35 & 11.5 & 14.1 & 10.2 & 12.9 & 0.02 & 0.03 & 1.04 & 0.04 & 97.3 & 13 \\
\hline LT2-FT15 & & 45.9 & 1.67 & 0.29 & 0.28 & 11.6 & 14.9 & 10.4 & 12.0 & 0.03 & 0.05 & 1.02 & 0.06 & 98.1 & 17 \\
\hline LT2-FT2 & & 44.0 & 2.10 & 0.66 & 0.18 & 11.5 & 14.6 & 11.1 & 11.6 & 0.03 & 0.04 & 1.96 & 0.08 & 97.8 & 28 \\
\hline LT2-FT3 & & 44.9 & 1.99 & 0.44 & 0.20 & 12.1 & 14.9 & 11.1 & 11.1 & 0.03 & 0.05 & 1.31 & 0.08 & 98.1 & 33 \\
\hline Average & & $44.6 \pm 1.7$ & $1.98 \pm 0.28$ & $0.50 \pm 0.17$ & $0.20 \pm 0.10$ & $12.0 \pm 1.16$ & $15.1 \pm 1.1$ & $11.0 \pm 0.8$ & $10.9 \pm 1.9$ & 1 & 0.05 & 1.40 & 0.07 & & \\
\hline
\end{tabular}




\begin{tabular}{|c|c|c|c|c|c|c|c|c|c|c|c|c|c|c|c|}
\hline LT2-12 & \multirow{5}{*}{ Groundmass } & 73.6 & 0.90 & 2.28 & 0.04 & 12.5 & 0.27 & 1.11 & 2.22 & 0.04 & 0.02 & 0.5 & 0.02 & 93.5 & 5 \\
\hline LT2-18A & & 77.2 & 0.60 & 2.16 & 0.06 & 11.5 & 0.12 & 0.47 & 1.25 & 0.03 & 0.01 & 0.41 & 0.01 & 93.8 & 5 \\
\hline LT2-FT2 & & 75.1 & 1.99 & 2.68 & 0.07 & 13.5 & 0.07 & 1.41 & 0.77 & 0.06 & 0.03 & 0.15 & 0.04 & 95.8 & 5 \\
\hline LT2-FT3 & & 77.8 & 0.58 & 2.03 & 0.05 & 10.8 & 0.13 & 0.60 & 1.38 & 0.04 & 0.02 & 0.36 & 0.01 & 93.8 & 5 \\
\hline Average & & $75.9 \pm 2.5$ & $1.01 \pm 0.89$ & $2.29 \pm 0.55$ & 1 & $12.1 \pm 1.7$ & $0.15 \pm 0.08$ & $0.90 \pm 0.73$ & $1.40 \pm 0.54$ & 0.04 & 1 & 0.35 & 1 & & \\
\hline LT2-10A & \multirow{5}{*}{$\mathrm{Ol}$} & 37.6 & 0.01 & 0.02 & 0.52 & 0.12 & 35.6 & 0.27 & 24.6 & 0.16 & 0.05 & 0.03 & 0.03 & 98.9 & 6 \\
\hline LT2-9 & & 38.9 & 0.01 & 0.01 & 0.43 & 0.17 & 39.1 & 0.20 & 21.6 & 0.03 & 0.05 & 0.04 & 0.03 & 100.6 & 5 \\
\hline LT2-FT22 & & 40.9 & b.d.1. & b.d.l. & 0.17 & b.d.l. & 47.3 & 0.14 & 12.3 & 0.01 & 0.19 & 0.05 & 0.02 & 101.1 & 2 \\
\hline LT2-FT1A & & 39.2 & 0.01 & 0.01 & 0.34 & 0.03 & 41.4 & 0.17 & 19.3 & 0.02 & 0.06 & 0.04 & 0.03 & 100.6 & 10 \\
\hline Average & & $38.8 \pm 1.0$ & 1 & 1 & $0.39 \pm 0.12$ & 1 & $39.9 \pm 3.7$ & $0.20 \pm 0.05$ & $20.6 \pm 3.9$ & 1 & 0.07 & 1 & 1 & & \\
\hline LT2-12 & \multirow{7}{*}{ Opx } & 54.4 & 0.04 & 0.01 & 0.59 & 1.24 & 26.4 & 1.65 & 15.2 & 0.15 & 0.05 & 0.15 & 0.03 & 99.8 & 3 \\
\hline LT2-18A & & 55.0 & 0.02 & 0.01 & 0.59 & 1.20 & 27.9 & 0.82 & 14.4 & 0.12 & 0.02 & 0.09 & 0.03 & 100.4 & 11 \\
\hline LT2-9 & & 54.1 & 0.03 & 0.03 & 0.42 & 1.37 & 26.1 & 1.78 & 14.7 & 0.01 & 0.06 & 0.39 & b.d.l. & 99.0 & 1 \\
\hline LT2-FT14 & & 53.6 & 0.01 & 0.01 & 0.74 & 1.98 & 26.0 & 0.43 & 16.4 & 0.02 & 0.04 & 0.09 & b.d.l. & 99.3 & 6 \\
\hline LT2-FT15 & & 50.9 & 0.36 & 0.13 & 0.64 & 4.61 & 20.5 & 2.07 & 16.9 & 0.01 & 0.02 & 0.23 & 0.05 & 96.3 & 6 \\
\hline LT2-FT2 & & 54.1 & 0.02 & 0.01 & 0.65 & 1.88 & 26.2 & 0.73 & 16.6 & 0.03 & 0.04 & 0.11 & 0.05 & 100.4 & 5 \\
\hline Average & & $53.7 \pm 2.0$ & 1 & 1 & $0.63 \pm 0.19$ & $2.10 \pm 1.80$ & $25.7 \pm 3.9$ & $1.07 \pm 1.57$ & $15.7 \pm 1.6$ & 1 & 1 & 0.14 & 1 & & \\
\hline LT2-10A & \multirow{10}{*}{$\mathrm{Pl}$} & 46.6 & 1.45 & 0.05 & 0.03 & 33.9 & 0.06 & 17.2 & 0.52 & 0.02 & 0.02 & 0.02 & 0.02 & 99.8 & 16 \\
\hline LT2-12 & & 51.0 & 3.37 & 0.12 & 0.05 & 30.7 & 0.06 & 13.7 & 0.60 & 0.02 & 0.04 & 0.02 & 0.02 & 99.8 & 6 \\
\hline LT2-18A & & 47.9 & 2.12 & 0.07 & 0.02 & 33.1 & 0.04 & 16.0 & 0.43 & 0.03 & 0.02 & 0.02 & 0.02 & 99.7 & 15 \\
\hline LT2-9 & & 47.9 & 2.03 & 0.08 & 0.03 & 32.8 & 0.08 & 16.2 & 0.60 & 0.03 & 0.03 & 0.03 & 0.03 & 99.7 & 20 \\
\hline LT2-FT22 & & 49.7 & 2.81 & 0.13 & 0.04 & 31.8 & 0.09 & 14.9 & 0.80 & 0.02 & 0.02 & 0.03 & 0.02 & 100.4 & 8 \\
\hline LT2-FT14 & & 54.8 & 5.23 & 0.14 & 0.04 & 28.1 & 0.01 & 10.5 & 0.17 & 0.02 & 0.03 & 0.02 & 0.03 & 99.1 & 17 \\
\hline LT2-FT15 & & 50.0 & 3.96 & 0.13 & 0.04 & 28.4 & 0.05 & 14.7 & 0.30 & 2.49 & 0.03 & 0.02 & 0.02 & 99.8 & 19 \\
\hline LT2-FT1A & & 45.5 & 1.75 & 0.06 & 0.02 & 32.9 & 0.19 & 16.0 & 0.63 & 0.01 & 0.02 & 0.03 & 0.02 & 97.1 & 8 \\
\hline LT2-FT2 & & 49.8 & 3.08 & 0.12 & 0.04 & 31.4 & 0.03 & 14.4 & 0.37 & 0.01 & 0.05 & 0.04 & 0.05 & 99.3 & 7 \\
\hline LT2-FT3 & & 48.1 & 2.22 & 0.08 & 0.01 & 32.7 & 0.04 & 16.0 & 0.41 & 0.02 & 0.03 & 0.03 & 0.03 & 99.6 & 11 \\
\hline
\end{tabular}


Table S3 Estimated mineral modes for Lutao volcanics based on optical microscopy. The CaO contents of Ol, Cpx, Opx, $\mathrm{Hbl}$, and Pl are derived from Table S2.

\begin{tabular}{|c|c|c|c|c|c|c|c|c|c|c|c|c|c|c|c|c|c|}
\hline \multirow[b]{2}{*}{ sample } & \multicolumn{6}{|c|}{ Mineral mode (\%) } & \multirow{2}{*}{$\begin{array}{c}\text { measured } \mathrm{CaO} \\
\quad \text { (wt.\%) }\end{array}$} & \multirow{2}{*}{$\begin{array}{c}\text { modeled } \mathrm{CaO} \\
(\text { wt. } \%)\end{array}$} & \multicolumn{5}{|c|}{$\% \mathrm{CaO}$ in minerals } & \multicolumn{4}{|c|}{$\delta^{44 / 40} \mathrm{Ca}$ of minerals } \\
\hline & $\mathrm{Ol}$ & Cpx & Opx & $\mathrm{Hbl}$ & Plg & groundmass & & & $\mathrm{Ol}$ & Cpx & Opx & $\mathrm{Hbl}$ & $\mathrm{Plg}$ & Plg & Cpx & Opx & $\mathrm{Hbl}$ \\
\hline LT2-FT1A & 6 & 18 & 24 & 6 & 36 & 10 & 10.6 & 10.6 & 0.1 & 36 & 2 & 6 & 54 & 0.77 & 0.96 & 1.56 & 0.98 \\
\hline LT2-FT2 & 0 & 3 & 16 & 31 & 10 & 40 & 6.1 & 6.1 & 0 & 11 & 3 & 56 & 24 & 0.59 & 0.78 & 1.38 & 0.80 \\
\hline LT2-FT3 & 0 & 3 & 14 & 33 & 14 & 35 & 6.9 & 7.1 & 0 & 9 & 2 & 52 & 33 & 0.79 & 0.98 & 1.56 & 1.00 \\
\hline LT2-9 & 5 & 15 & 20 & 5 & 40 & 15 & 10.2 & 10.6 & 0.1 & 30 & 2 & 5 & 61 & 0.88 & 1.07 & 1.67 & 1.09 \\
\hline LT2-10A & 5 & 15 & 15 & 15 & 30 & 20 & 10.5 & 10.4 & 0.1 & 31 & 2 & 16 & 50 & 0.90 & 1.09 & 1.69 & 1.11 \\
\hline LT2-12 & 0 & 4 & 11 & 14 & 36 & 35 & 7.8 & 7.7 & 0 & 10 & 1 & 21 & 64 & 0.77 & 0.96 & 1.56 & 0.97 \\
\hline LT2-FT14 & 0 & 0 & 9 & 18 & 23 & 50 & 4.9 & 4.9 & 0 & 0 & 2 & 41 & 48 & 0.87 & 1.06 & 1.66 & 1.08 \\
\hline LT2-FT15 & 0 & 0 & 8 & 21 & 25 & 45 & 6.3 & 6.6 & 0 & 0 & 1 & 36 & 57 & 0.75 & 0.94 & 1.54 & 0.96 \\
\hline LT2-18A & 0 & 3 & 10 & 17 & 24 & 45 & 7.0 & 7.0 & 0 & 10 & 2 & 27 & 55 & 0.86 & 1.05 & 1.65 & 1.07 \\
\hline LT2-FT22 & 5 & 11 & 21 & 5 & 37 & 20 & 9.2 & 8.8 & 0.1 & 26 & 3 & 7 & 63 & 0.75 & 0.94 & 1.54 & 0.96 \\
\hline
\end{tabular}

Fitting equations for Anorthite, Cpx with Ca of 7/16, and Opx with Ca of 1/48 are proposed as follows (Wang et al., 2017; Huang et al., 2019):

Anorthite: $1000 \ln \beta=6.21 \times 10^{-5} x^{3}-5.68 \times 10^{-3} x^{2}+1.307 x$, where $x=10^{6} / \mathrm{T}^{2}$

Cpx: $1000 \ln \beta=1.22 \times 10^{-4} x^{3}-7.28 \times 10^{-3} x^{2}+1.498 x$, where $x=10^{6} / \mathrm{T}^{2}$

Opx: $1000 \ln \beta=1.94 \times 10^{-4} x^{3}-0.013 x^{2}+2.104 x$, where $x=10^{6} / \mathrm{T}^{2}$

Temperature is set as $1000 \mathrm{~K}$ (Chen, 1986) 
Table S4 Endmember values used in the calculation of mixing models

\begin{tabular}{|c|c|c|c|c|c|c|c|c|c|c|c|c|c|}
\hline Endmember & References & ${ }^{87} \mathrm{Sr} /{ }^{86} \mathrm{Sr}$ & ${ }^{143} \mathrm{Nd} /{ }^{144} \mathrm{Nd}$ & $\mathrm{Sr}$ & $\mathrm{Nd}$ & $\mathrm{Ce}$ & $\mathrm{Pb}$ & $\mathrm{Nb}$ & Th & $\mathrm{La}$ & $\mathrm{Ba}$ & $\begin{array}{l}\mathrm{CaO} \\
\text { (wt.\%) }\end{array}$ & $\delta^{44 / 40} \mathrm{Ca}$ \\
\hline$\overline{\text { DMM }}$ & Workman and Hart & 0.70263 & 0.51313 & 7.66 & 0.58 & 0.550 & 0.018 & 0.1485 & 0.0079 & 0.192 & 0.563 & 3.17 & $0.94 \pm 0.05 \%{ }^{\mathrm{a}}$ \\
\hline D-DMM & (2005) & 0.70219 & 0.51326 & 6.092 & 0.483 & & & & & & & & \\
\hline $\mathrm{AMMF}^{\mathrm{b}}$ & This study & 0.70367 & 0.51274 & 290 & 12 & 12.2 & 5.1 & $1.0^{\mathrm{c}}$ & 2.3 & 8.1 & 252 & 7.8 & $1.0 \%$ \\
\hline Site 1144 SCS sediments & Wei et al. (2004) & $0.71236^{\mathrm{d}}$ & $0.51221^{\mathrm{d}}$ & 301 & 33.8 & 74.7 & 21.7 & 16.1 & 13.5 & 38.2 & 528 & 7.4 & $-0.2 \% 0-0.36 \% 0^{\mathrm{e}}$ \\
\hline UCC & Rudnick and Gao, 2003 & $0.71236^{\mathrm{d}}$ & $0.51221^{\mathrm{d}}$ & 320 & 27 & 63 & 17 & 12 & 10.5 & 31 & 628 & 3.59 & $0.72 \pm 0.10 \% 0^{\mathrm{f}}$ \\
\hline
\end{tabular}

${ }^{a}$ Proposed by Kang et al. (2017) from fertile spinel and garnet peridotites.

${ }^{\mathrm{b}}$ The chemical compositions of AMMF are estimated from the correlations between log (elements) and ${ }^{87} \mathrm{Sr} /{ }^{86} \mathrm{Sr}$ of the Lutao arc magmas. The Sr-Nd isotopic compositions of AMMF are derived from that of the most depleted Lutao volcanic rock sample.

${ }^{\mathrm{c}}$ Due to the large uncertainty in calculating the endmember $\mathrm{Nb}$ content in Fig. S6, the estimated endmember Nb content (1.8 ppm) of AMMF was arbitrary modified as 1.0 ppm to represent the maximum $\mathrm{Sr} / \mathrm{Nb}$ and $\mathrm{Ce} / \mathrm{Pb}$ ratios of the Lutao arc magmas.

d derived from Plank (2014) reporting on global subducting sediment (GLOSS-II).

${ }^{\mathrm{e}} 0.36 \%$ is the weighted average $\delta^{44 / 40} \mathrm{Ca}$ value of carbonate-rich sediment at Site 144 (Zhu et al., 2020).

${ }^{\mathrm{f}}$ Proposed by Wang et al. (2019). 
Table S5 Thermal structures, chemical compositions of subducting sediments, and flux of sedimentary Ca subducted into global trenches

\section{See the attached excel file}

\section{References}

Chen Chang-Hwa, Shieh Y.-N., Lee T., Chen Cheng-Hong and Mertzman S. A. (1990) Nd-Sr-O isotopic evidence for source contamination and an unusual mantle component under Luzon Arc. Geochim. Cosmochim. Acta 54, 2473-2483.

Chen J. and Lin F. (1980) Geochemistry of Lutao andesites. Acta Ocean. Taiwanica 11, 49-69.

Chen C.-H. (1986) Petrology and genesis of cognate plutonic inclusions in andesites of East Coastal Range, Lutao and Lanhsu, Taiwan. Mem Geol Soc China 7, 259-281.

Defant M. J., Maury R. C., Joron J.-L., Feigenson M. D., Leterrier J., Bellon H., Jacques D. and Richard M. (1990) The geochemistry and tectonic setting of the northern section of the Luzon arc (the Philippines and Taiwan). Tectonophysics 183, 187-205.

Heuser A. (2016) Biomedical application of Ca stable isotopes. In Calcium stable isotope geochemistry. Springer. pp. 247-260.

Huang F., Zhou C., Wang W., Kang J. and Wu Z. (2019) First-principles calculations of equilibrium Ca isotope fractionation: Implications for oldhamite formation and evolution of lunar magma ocean. Earth Planet. Sci. Lett. 510, 153-160.

Kang J.-T., Ionov D. A., Liu F., Zhang C.-L., Golovin A. V., Qin L.-P., Zhang Z.-F. and Huang F. (2017) Calcium isotopic fractionation in mantle peridotites by melting and metasomatism and $\mathrm{Ca}$ isotope composition of the Bulk Silicate Earth. Earth Planet. Sci. Lett. 474, 128-137.

Keken P. E. van, Hacker B. R., Syracuse E. M. and Abers G. A. (2011) Subduction factory: 4. Depthdependent flux of $\mathrm{H}_{2} \mathrm{O}$ from subducting slabs worldwide. J. Geophys. Res. Solid Earth 116, B01401.

Liu X. (2020) Provenance and evolution of sediments at Site U1431 from the East Subbasin of the South China Sea. Masters, Zhejiang University. 
Marini J.-C., Chauvel C. and Maury R. C. (2005) Hf isotope compositions of northern Luzon arc lavas suggest involvement of pelagic sediments in their source. Contrib. Mineral. Petrol. 149, 216232.

McDermott F., Defant M. J., Hawkesworth C. J., Maury R. C. and Joron J. L. (1993) Isotope and trace element evidence for three component mixing in the genesis of the North Luzon arc lavas (Philippines). Contrib. Mineral. Petrol. 113, 9-23.

McDonough W. F. and Sun S. S. (1995) The composition of the Earth. Chem. Geol. 120, 223--253.

Plank T. (2014) The Chemical Composition of Subducting Sediments. In Treatise on Geochemistry. Elsevier. pp. 607-629.

Plank T. and Manning C. E. (2019) Subducting carbon. Nature 574, 343-352.

Rudnick R. L. and Gao S. (2003) Composition of the continental crust. In The Crust. Elsevier-Pergamon, Oxford.

Scholl D. W. and von Huene R. (2007) Crustal recycling at modern subduction zones applied to the past-Issues of growth and preservation of continental basement crust, mantle geochemistry, and supercontinent reconstruction. In Geological Society of America Memoirs. Geological Society of America. pp. 9-32.

Sun S. s and McDonough W. F. (1989) Chemical and isotopic systematics of oceanic basalts: implications for mantle composition and processes. Geol. Soc. Lond. Spec. Publ. 42, 313-345.

Syracuse E. M., van Keken P. E. and Abers G. A. (2010) The global range of subduction zone thermal models. Phys. Earth Planet. Inter. 183, 73-90.

Wang W., Zhou C., Qin T., Kang J.-T., Huang S., Wu Z. and Huang F. (2017) Effect of Ca content on equilibrium $\mathrm{Ca}$ isotope fractionation between orthopyroxene and clinopyroxene. Geochim. Cosmochim. Acta 219, 44-56.

Wang Y., He Y., Wu H., Zhu C., Huang S. and Huang J. (2019) Calcium isotope fractionation during crustal melting and magma differentiation: Granitoid and mineral-pair perspectives. Geochim. Cosmochim. Acta 259, 37-52.

Wei G., Liu Y., Li X., Shao L. and Fang D. (2004) Major and trace element variations of the sediments at ODP Site 1144, South China Sea, during the last $230 \mathrm{ka}$ and their paleoclimate implications. Palaeogeogr. Palaeoclimatol. Palaeoecol. 212, 331-342. 
Workman R. K. and Hart S. R. (2005) Major and trace element composition of the depleted MORB mantle (DMM). Earth Planet. Sci. Lett. 231, 53-72.

Yang T. F. (1992) Magma evolution of the North Luzon arc and its tectonic implication. Ph.D., National Taiwan University.

Zhu H., Liu F., Li X., An Y., Nan X., Du L., Huang F., Sun W. and Zhang Z. (2020) Significant $\delta^{44 / 40}$ Ca variations between carbonate- and clay-rich marine sediments from the Lesser Antilles forearc and implications for mantle heterogeneity. Geochim. Cosmochim. Acta 276, 239-257.

Zindler A. and Hart S. (1986) Chemical geodynamics. Annu. Rev. Earth Planet. Sci. 14, 493-571. 